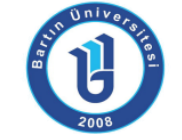

ISSN: 1308-7177
Bartin University

Journal of Faculty of Education

Volume 5, Issue 2, p. 247 - 272, June 2016

BARTIN - TURKEY

Doi: 10.14686/buefad.v5i2.5000164182

\title{
Otizm Spektrum Bozukluğu Olan Bireylere Sosyal Beceri Öğretiminde Bilgisayar Destekli Öğretim Uygulamalarının Gözden Geçirilmesi
}

Mine KiziR, Öğretim Görevlisi, Muğla Sıtkı Koçman Üniversitesi, Eğitim Fakültesi, minekizir@mu.edu.tr Ahmet YIKMIŞ, Yrd. Doç. Dr., Abant İzzet Baysal Üniversitesi Eğitim Fakültesi, yikmis_a@ibu.edu.tr

Öz: Bu çalışma, 2005-2015 yılları arasında, bilimsel dayanaklı bir uygulama olan Bilgisayar Destekli Öğretim (BDÖ) ile Otizim Spektrum Bozukluğu (OSB) olan çocuklara sosyal beceri öğretmeyi hedefleyen araştırmaların analiz edilmesi amacıyla yapılmıştır. Çalışma, Muğla Sıtkı Koçman Üniversitesi veri tabanı üzerinden EBSCO-Host, ERIC, PsycINFO, Academic Search Complete ve Google elektronik veri tabanları üzerinden taranarak ulaşılabilen 13 araştırmayı kapsamaktadır. Ulaşılan çalışmalar, OSB'si olan, 5-12, 12-17 ve 17 yaş ve üstü aralığındaki 401 katılımcı ile yürütülmüştür. Araştırmaların OSB'li bireylere sosyal beceri öğretiminde BDÖ’nün etkililiğini belirlemek amacıyla uygulamalar yapmış oldukları görülmektedir. Araştırmaların bazılarında aynı yazılım programları kullanılırken bazılarında ise farklı türde yazılım programlarının kullanıldığı belirlenmiştir. Araştırmalarda; "Mind Reading”, "Collobrative Virtual Learning Environment (CVLE) - 3D Emphaty System", "FaceSay" ${ }^{\mathrm{TM}}$ ", "Juniour Detective Training Program", "MS Powerpoint ve Adobe Photoshop 5.0", "Let!s Face It", "The Educational Software" ve "Virtual Reality Social Cognition Training" yazılım programları kullanılmıştır. Yapılan tüm uygulamaların, araştırmalarda hedeflenen sosyal becerileri edindirmede etkili oldukları bulgusuna ulaşılmıştır.

Anahtar Kelimeler: bilgisayar destekli öğretim, otizm spektrum bozukluğu, asperger sendromu, sosyal beceri, sosyal beceri öğretimi,

\section{Revising Computer-Aided Instruction Applications in Social Skills Training of Individuals with Autism Spectrum Disorder}

\footnotetext{
Abstract: The objective of the present study was to analyze the studies that aimed to instruct social skills to children with Autism Spectrum Disorder using Computer-Based Instruction (CBI), a scientific application, during $2005-2015$ period. The study included 13 studies that were accessed using Muğla Sıtkı Koçman University database and using EBSCO-Host, ERIC, PsycINFO, Academic Search Complete and Google electronic databases. The accessed studies were conducted with 401 participants, who were aged $5-12,12-17$, and 17 and older. It was observed that the researchers conducted studies to determine the effectiveness of $\mathrm{CBI}$ in social skills instruction to the individuals with ASD. While similar software programs were used in various studies, in some others different software programs were utilized. "Mind Reading", "Collaborative Virtual Learning Environment (CVLE) - 3D Empathy System", "FaceSay' ${ }^{\mathrm{TM}}$ ", "Junior Detective Training Program", "MS PowerPoint and Adobe Photoshop 5.0", "Let's Face It", "The Educational Software" and "Virtual Reality Social Cognition Training" software were used in the studies. It was found that all applications were effective in gaining the targeted social skills in the studies.
}

Key Words: computer-based instruction, autism spectrum disorder, asperger syndrome, social skill, social skill instruction 


\section{GiRiş}

Otizm Spektrum Bozukluğu, sosyal alanlarda ortaya çıkan, iletişim ve etkileşimdeki yetersizlikler, sınırlı, yineleyici davranışlar, ilgiler veya etkinlikler ile kendini gösteren nörogelişimsel bir bozukluk olarak tanımlanmaktadır (APA, 2013). Otizm Spektrum Bozukluğu (OSB) olan bireyler pek çok alanda yetersizlik gösterebilmektedirler; bunlar, olağan dışı sosyal etkileşim ve sıra alama davranışının gelişememesinden, ilgilerini, duygularını paylaşamamaya, etkileşimi başlatamamaya ya da toplumsal etkileşime girememeye dek değişen aralıkta, sosyalduygusal karşılık eksikliği söz konusu olabilmektedir (Tekin-Ersan, 2015). OSB'si olan bireyler bilişsel ve dil becerileri alanlarındaki yeterlilikleri doğrultusunda yüksek veya düşük işlevli olarak sınıflandırılabilmektedir (Boucher, Mayes ve Bigham, 2008; Boucher, Bigham, Mayes ve Muskett, 2008). OSB'si olan bireylerin toplumsal yaşama katılımlarını kolaylaştırmak veya sosyal becerileri edinimlerini amaçlayan pek çok müdahale bulunmaktadır. OSB'li bireylerin gelişimlerini hedefleyen müdahalelerin etkililiklerini belirleyebilmek amacıyla Ulusal Otizm Merkezi (National Autism Center-NAC) sistematik çalışmalar yapmışlardır. Yapmış oldukları çalışmalarda OSB'li bireylere yönelik olarak kullanılan müdahale yöntemlerini çeşitli ölçütlere göre sınıflandırmış ve Ulusal Standartlar Raporunda (National Standarts Report) yayınlamışlardır. Bu rapora göre uygulanan müdahale yöntemleri (a) bilimsel dayanaklı, (b) umut vadeden ve (c) bilimsel dayanaktan yoksun uygulamalar olmak üzere üç şekilde sınıflandırmaktadırlar (NAC,2009, s. 38).

Wang ve diğerlerinin (2015), yayımlamış olduğu rapor doğrultusunda, uygulanan müdahalelerden 27'sinin bilimsel dayanaklı olabilme ölçütlerini karşıladığı görülmektedir. Buna göre sosyal öyküler, ayrımlı pekiştirme, model olma, doğal yaklaşımlar, temel tepki öğretimi, akran öğretimi, olumlu davranış desteği, ayrık denemeler ve görsel destek, bilimsel dayanaklı uygulamalardan bazılarıdır. Sözü edilen bilimsel dayanaklı uygulamalardan biri de teknoloji destekli öğretim ve müdahale yöntemleridir. Yöntem, teknoloji şemsiyesi altında çeşitli uygulamaları içerisinde barındırmaktadır. Bu şemsiye altında, konuşma üreten aletler, akılı telefonlar, tabletler, sanal ağlar ve Bilgisayar Destekli Öğretim-BDÖ (Computer-Based Instruction / CBI) yöntemi bulunmaktadır (Wang ve diğ., 2015). Bu çalışmada OSB'li bireylerin sosyal becerilerde yaşadıkları sorunlar da dikkate alınarak bu becerilerde, BDÖ yöntemi ile yapılmış olan çalışmalar incelenecektir.

Bilgisayarla öğretim, ilk olarak psikologlar tarafından geliştirilmiştir ve öğrenmeöğretme ilkelerini temel almaktadır. Bu yöntem özünde öğretme yöntemlerinin elektronik araçlar aracılığıyla uygulanması ve sunulması esasına dayanmaktadır (Alkan, 1998, s. 182). BDÖ, öğrencilerin bilgisayar veya tablet gibi araçlarla, öğrenme hızlarına uygun, gösterecekleri tepkiler dikkate alınarak hazırlanmış yazııım programları ile yapılan bir öğretim türü olarak tanımlanabilmektedir (Demirel, Seferoğlu ve Yağcı, 2003, s. 134). BDÖ’nün günümüz çağı bilgisayar teknolojileri ve bu teknolojilere her gün bir yenilik eklendiği düşünülecek olursa eğitim ortamlarında oldukça geniş bir uygulama alanı bulması kaçınılmaz olmaktadır. Bu yöntem, eğitim ortamlarında ve süreçlerinde etkililiği, devamlı olmayı ve bütüncül bir bakış açısını hedef almaktadır (Alkan, 1998, s. 185). BDÖ, bilgisayar teknolojisi dendiğinde akla gelen her türlü; iletişimi, enformasyon teknolojisinin eğitim-öğretim amaçlı kullanımını, çoklu öğretim ortamlarını, sanal gerçeklik, yapay zekâ gibi uygulamaları ve eğitim ortamlarına katkı sağlayan tüm teknik, model ve yaklaşımları içermektedir (Bayram, 2006).

BDÖ'de eğitim-öğretim etkinliklerinin yürütülebilmesi için çeşitli yazılım programlarının geliştirilmesine ihtiyaç duyulmaktadır. Bu amaçla kullanılmak üzere geliştirilmiş olan yazılım programları eğitimin hemen hemen her alanında kullanılabilmektedir. Yazılım programlarının 
hazırlanması, geliştirilmesi ve uygunluğunun değerlendirilmesi özenli bir çalışmayı gerekli kılmaktadır. Bu yazılım programları temel olarak "alıştırma ve pratik yaptırma", "öğretici", "benzetim", "problem çözme" ve "eğitsel oyunlar" şeklinde sınıflandırılabilir (Demirel ve diğ., 2003 , s. 134-135). Eğitim ve öğretim ortamlarında kullanılacak olan yazılım programlarını seçerken öğrencinin yaşı, ilgi alanları ve beceri düzeyleri dikkate alınmalıdır (Halis, 2001, s. 228). Ayrıca yazılımı seçerken, konular sistemli ve akıcı bir şekilde verilmeli, öğretimi yapılacak konuyla ilişkili en az ve en çok süreler belirtilmelidir. (Doğan, 2003, s. 222). Bu şekilde BDÖ ile sunulacak eğitim ve öğretim oturumlarının daha etkin olması sağlanmalıdır. Yazılım programını geliştirme sürecinde, yazılımın kullanılacağı dersin konusu belirlenmeli ve öğrencilerin ihtiyaçları göz önünde bulundurulmalıdır. Öncelikle yazılımı kullanacak olan öğrencilerin özellikleri belirlenmeli, hedefler ortaya konmalı ve daha sonra içerik, öğrenme yöntem ve ilkelerine uygun olarak düzenlenmelidir (Halis, 2001, s. 231). BDÖ'nün etkili bir şekilde sunulması uygun ve kaliteli yazılım programları geliştirilmesi ve kullanılmasıyla mümkün olmaktadır. BDÖ ile yapılan eğitim sonrasında ulaşılmak istenen hedeflere ulaşılamıyor veya konuyu öğretmekte yetersiz kalıyorsa bu durum yazılım programının seçiminin hatalı olduğunu göstermektedir (Demirel ve diğ., 2003, s. 133).

BDÖ’nün eğitim-öğretimde kullanılmasının pek çok yararı bulunmaktadır. Bunlar; öğrenciyi güdülemesi, ilgi çekici olması, kalıcı yaşantılar kazandırması, bilginin yanı sıra beceri ve davranışları geliştirmesi, öğretimde unutmayı geciktirmesi, öğretimi zevkli, çekici, eğlendirici hale getirmesi, uygulama zenginliğine sahip olması, ihtiyaca uygun eğitimi gerçekleştirmesidir (Doğan, 2003, s. 214-215). Ayrıca, öğrenme sürecini hızlandırması nedeniyle öğretmene ve öğrenciye daha çok zaman kazandırmaktadır. Bilgisayarla oluşturulan simülasyonların ve modeller sayesinde, öğrencinin algılamasını, zihinde tutmasını kolaylaştırmakta ve tekrar edilebilir nitelikte olmaktadır (Halis, 2001, s. 231). Ek olarak, öğrencilerin aktif bir şekilde öğrenme sürecine girmelerini ve öğrencilerin kendi hızları ile konuları öğrenmelerine olanak sağlamaktadır (Demirel ve diğ., 2003, s. 131). BDÖ’nün sözü edilen yararlarının OSB'si olan bireyler için de geçerli olduğu bunun yanı sıra, eğitimlerinde kullanılmasının, onların sosyal ortamlarda hissettikleri olumsuz duyguların, sanal gerçeklik gibi yazılım programları sayesinde azalabileceği söylenebilir.

BDÖ’nün sayılan tüm bu yararları özel gereksinimli öğrenciler için de söz konusu olmaktadır. Özel eğitimde BDÖ'nün kullanılması ile özel gereksinimli bireyin derse ilgisinin artacağı ve öğrenmesinin daha kolay olacağı düşünülmektedir (Doğan ve Akdemir, 2015). Özel eğitim çatısı altında bulunan, OSB'li bireylerin eğitimlerinde de bilgisayarların eğitim amacıyla kullanılmasının onlar için yararlı olacağı söylenebilir (Halis, 2001, s. 228). OSB'li bireylere yönelik hazırlanacak olan bilgisayar yazılımları değişik amaçlar için rahatlıkla kullanılabilir (Bayram, 2006). OSB'li bireylerin bireysel farklılıklarına, ilgi ve gereksinimlerine uygun olarak hazırlanan yazılımların kullanımıyla, bu bireylere sosyal, okur-yazarlık, iletişim, akademik beceriler vb. gibi beceri alanlarında öğretim, etkili bir şekilde yapılabilmektedir (Luiselli, 2014, s. 85).

BDÖ’ye ilişkin alan yazın incelendiğinde bilgisayarlar, konuşma üreten cihazlar, tabletler, akıllı telefonlar kullanılarak pek çok beceri alanında uygulama yapılmış olduğu görülmektedir. Hetzroni ve Tannous (2004), BDÖ’nün OSB'li bireylerin, gecikmiş konuşma, ekolali, bir konuyla ilişkili ve ilişkisiz konuşma ve iletişimi başlatma becerileri üzerinde çalışılmış ve bu konulardaki yetersizliklerinin geliştirilmesinde BDÖ’nün etkisini incelemişlerdir. Araştırma sonucuna göre katılımcı tüm çocuklar, hedeflenen iletişim becerilerinde gelişim göstermişlerdir ve BDÖ etkili olduğu sonucuna ulaşmışlardır. Simpson ve diğerleri (2004), video model yöntemi ile BDÖ’nün birlikte kullanımının OSB'li çocukların sosyal becerilerinin gelişimi üzerine etkilerini araştırmışlardır. Araştırmada OSB'li bireylerin, diğer insanlarla paylaşımda 
bulunması, öğretmenin yönergelerine uyması ve selamlaşma becerilerinin geliştirilmesi amaçlanmıştır. Araştırmanın sonucunda, katılımcıların tamamı hızlı bir şeklide hedeflenen sosyal becerileri edinmişlerdir. Diğer bir çalışma ise Ramdoss ve diğerlerinin (2012) yapmış olduğu alan yazın taramasıdır. Araştırma kapsamında 1990-2010 yılları arasında BDÖ ile sosyal ve duygusal beceri öğretimini konu alan 12 çalışma incelenmiştir. İncelenen çalışmaların ışığında BDÖ’nün OSB'li çocuklara sosyal ve duygusal beceri kazandırmada etkili olduğu sonucuna ulaşılmıştır.

Yapılan alan yazın taraması sonucunda 2005-2015 yılları arasını kapsayan ve BDÖ’nün OSB'li bireylerde sosyal beceri öğretiminde etkili olup olmadığını inceleyen çalışmalardan oluşan bir betimsel analiz çalışmasına rastlanmamıştır. Bilgisayar teknolojisindeki ilerlemeler dikkate alındığında, son yıllarda OSB'li bireylere sosyal beceri öğretimi alanına yapılmış olan katkıların gözden geçirilmesi gerekliliği doğmuştur. Bilimsel dayanaklı bir uygulama olan BDÖ alanında yapılan çalışmaların betimsel analizinin uygulamacı ve araştırmacılara yön vermesi de umulmaktadır. Bu araştırmanın temel amacı, OSB'li bireylere sosyal beceri öğretimi üzerine çalışan uygulamacı ve araştırmacılara, yapılan çalışmaları sistematik bir şekilde derleyerek ihtiyaç duyabilecekleri bilgiyi sunmaktır. Bu amaçla uluslararası hakemli dergilerde yayımlanan ve 2005-2015 yılları arasında çalışılan araştırmalara ulaşılmıştır. OSB'li bireylere BDÖ aracılığı ile sosyal beceri edindirmeyi amaçlayan ve yapılan alan yazın taraması sonucunda ulaşılan araştırmalarda aşağıdaki sorulara cevaplar aranmış ve analiz yapılımıştır.

1. Incelenen araştırmalarda katılımcı sayısı, yaş, cinsiyet ve tanı bağlamında katılımcı özellikleri nasıldır?

2. Araştırmalarda hedeflenen sosyal beceriler, araştırma modeli, geçerlik ve güvenirlik konularına ilişkin yöntemsel özellikleri nasıldır?

3. Araştırmalarda kullanılan yazılım ve donanımlar nelerdir?

4. Araştırmaların gerçekleştiği ortam, uygulama süresi ve uygulamanın yapılışına ilişkin uygulama özellikleri nasıldır?

5. Araştırmalarda izleme ve genelleme çalışmaları yapılmış mıdır?

6. Araştırmaların bulgularına göre etkililik düzeyi nasıldır?

\section{YÖNTEM}

Bu bölümde araştırmanın modeli, araştırma alanı, verilerin toplanması ve analizi bilgilerine yer verilecektir.

\subsection{Araştırma Modeli}

Araştırma kapsamında ulaşılan çalışmaların analizlerinin yapılabilmesi için araştırma modeli olarak nitel araştırma yöntemlerinden doküman inceleme kullanılmıştır. Dokümanlar, nitel araştırmalarda önemli bilgi kaynaklarıdır ve etkili bir şekilde kullanmayı gerekli kılar. Yıldırım ve Şimşek (2008, s.187), doküman incelemesi tekniğini, "Araştırılması hedeflenen olgu veya olgular hakkında bilgi içeren yazılı materyallerin analizi" olarak tanımlamaktadırlar. Bu araştırma da yapılan çalışmaların yayımlanmış dokümanlarında verilen bilgiler dikkate alınarak sistemli bir inceleme yapılacaktır.

\subsection{Araştırma Alanı}

Bu çalışma 2005-2015 yılları arasında, bilimsel dayanaklı bir uygulama olan BDÖ ile OSB'li çocuklara sosyal beceri öğretmeyi hedefleyen araştırmaların analiz edilmesi amacıyla yapılmaktadır. Bu amaçla, araştırmaya dâhil edilecek olan çalışmalara ulaşabilmek için bazı 
ölçütler belirlenmiştir. Bu ölçütlerden ilki araştırmaların 2005 ve 2015 yılları arasında deneysel olarak gerçekleştirilmiş ve hakemli bir dergide yayımlanmış olmalarıdır. Bilgisayar alanında her geçen gün yeni teknolojilerin geliştiriliyor olması çalışmaya yıl sınırlaması getirme gereksinimini doğurmuştur. Alanda çalışan uzmanlara yol göstermesi bakımından bu çalışmada son dönemde kullanılmış olan güncel yazılım programları ve uygulamaların sunulması amaçlanmaktadır. Dolayısıyla çalışmaya son on yılda yapıımış olan araştırmalar dâhil edilmiştir. İkinci ölçüt katıımcıların OSB tanısı almış olmalarıdır. Bilindiği üzere 2013 yılında DSM IV tanı ölçütleri değiştirilerek DSM V yürürlüğe girmiştir. Dolayısıyla araştırma kapsamında hem DSM IV hem de DSM V tanı ölçütlerine göre tanı almış gruplar dikkate alınmıştır. Bu nedenle katılımcıların Yaygın Gelişimsel Bozukluk şemsiyesi altında kalan; Asperger Sendromu, OSB, Rett Sendromu, Çocukluk Çağı Dezintegratif Bozukluğu ve Başka Türlü Adlandırılamayan Yaygın Gelişimsel Bozukluk olması da belirlenen ölçütü karşılamaktadır. Diğer bir ölçüt ise çalışmaların deneysel olması ve BDÖ uygulanarak bir veya birden fazla sosyal beceri öğretmeyi hedeflemesi gerekmektedir. Söz konusu ölçütleri karşılayan 21 çalışmaya ulaşılabilmiştir. Ulaşılan çalışmalardan üçü BDÜ'nün yanı sıra başka bir yöntemi kullandığı, diğer iki çalışmada nitel araştırma yöntemi ile gerçekleştirildiği ve diğerleri kullanılan yazılım programı hakkında bilgi vermeye yönelik çalışmalar olduğu için araştırmaya dâhil edilmemişlerdir. Sonuç olarak araştırma alanını 13 çalışma oluşturmuştur.

\subsection{Verilerin Toplanması}

Çalışmada makalelerinin taranması sürecinde Muğla Sıtkı Koçman Üniversitesi veri tabanı üzerinden EBSCO-Host, ERIC, PsycINFO, Academic Search Complete ve Google elektronik veri tabanları taranmıştır. Araştırma kapsamına dâhil edilecek makaleler taranırken OSB (Autism Spectrum Disorder), Asperger Sendromu (Asperger Syndrome), Yaygın Gelişimsel Bozukluk (Pervasive Developmental Disorders), sosyal beceri (social skill), sosyal beceri öğretimi (social skill training/teaching), Bilgisayar Destekli Öğretim/ Eğitim (Computer Based Intervention/ Computer Assisted Instruction/ Technology/Training) anahtar sözcükleri kullanılmıştır. Ulaşılan tüm araştırmaların başlıkları ve özetleri gözden geçirilerek ölçütleri karşılamayanlar araştırmaya dâhil edilmemişlerdir. Ön tarama sonucunda ulaşılan çalışmalar ölçütler dikkate alınarak ayrıntılı bir şekilde okunmuş ve araştırma kapsamına alınacak çalışmalara karar verilmiştir. Yapılan tarama sonucunda ölçütler dâhilinde OSB'li olan bireylere sosyal beceri öğretiminde BDÖ kullanılan toplam 13 çalışmaya ulaşılabilmiştir.

\subsection{Verilerin Analizi}

Araştırma alanında ulaşılan çalışmaların yılları dikkate alınarak en eski tarihli olandan en yeni tarihli olma durumuna göre numara verilmiştir. Daha sonra araştırmacılar tarafından kategoriler belirlenmiştir. Araştırma kapsamında incelenen çalışmalara ilişkin kategoriler; (a) yaş, cinsiyet, tanı ve katılımcı sayısını içeren katılımcı özellikleri, (b) hedeflenen sosyal beceri, araştırma modeli, sosyal geçerlilik ve güvenirlik verilerini içeren yöntem özellikleri (c) yazılım, donanım, ortam, süre ve uygulamayı içeren uygulama özellikleri ve (d) etkililik, izleme ve genelleme bilgilerini içeren sonuç verilerinden oluşmuştur. Belirlenen kategoriler ile ilgili verilere ait bilgiler her bir kategori için oluşturulan tablolarda gösterilmektedir. Kategorilere ilişkin bilgiler, tartışma bölümünde ayrıntılı bir şekilde yorumlanarak ilgili araştırmalarla desteklenmiştir.

Ayrıca araştırmanın güvenirlik çalışması kapsamında araştırmacılar birbirlerinden bağımsız olarak alan yazın taraması gerçekleştirmiş ve ulaşılan tüm çalışmalar birleştirilerek araştırmaya dâhil edilecek çalışmalara karar verilmiştir. Bunun yanı sıra araştırmaya dâhil edilen tüm çalışmalar araştırmacılar tarafından ayrı ayrı ve ayrıntılı bir şekilde okunmuş ve 
ortak kategoriler belirlenmiştir. Belirlenen kategorilere ilişkin olarak her iki araştırmacı birlikte bir değerlendirme gerçekleştirmişlerdir. Daha sonra fikir birliğine varılan kategoriler üzerinden analiz yapılarak veriler ayrıntılı bir şekilde yorumlanmış ve ölçütlere göre tablolar oluşturulmuştur. Ek olarak ulaşılan çalışmaların \%30'u (4 araştırma) güvenirliği hesaplamak amacıyla yansız atama yoluyla seçilmiş ve özel eğitim alanında akademik çalışmalar yapan, OSB ve BDÖ konularında bilgiye sahip bir uzman tarafından okunmuştur ve sonuçlar Görüş Birliği / Görüş Birliği + Görüş Ayrılığı x 100 formülü kullanılarak hesaplanmıştır. Güvenirlik \% 92.1 olarak hesaplanmıştır.

\section{BULGULAR}

Araştırma kapsamında incelenen çalışmalardan edinilen bulgular uygulamaların gerçekleştiği tarihe göre numaralandırılmıştır ve sistemli bir şekilde tablolarda sunulmaktadır. Bulgular sunulurken Golan ve Baron-Cohen'in (2006) yapmış olduğu çalışma iki deneyi birden kapsaması nedeni ile oluşturulan tablolarda "Deney 1" ve "Deney 2" olarak gösterilmektedir.

\subsection{Katılımcı Özellikleri}

Katılımcı özellikleri; katılımcıların yaşı, cinsiyeti, tanısı ve katılımcı sayısı başlıklarına göre incelenerek elde edilen veriler Tablo 1'de gösterilmektedir.

Tablo 1.

Katılımcı Özellikleri ile Ilgili Bilgiler

\begin{tabular}{|c|c|c|c|c|c|}
\hline No & Yazarlar & $\begin{array}{l}\text { Katılımcı } \\
\text { Cinsiyeti }\end{array}$ & $\begin{array}{l}\text { Katılımcı } \\
\text { Yaşı }\end{array}$ & $\begin{array}{l}\text { Katılımcı } \\
\text { Tanıları }\end{array}$ & $\begin{array}{c}\text { Katılımcı } \\
\text { Sayısı }\end{array}$ \\
\hline \multirow[t]{2}{*}{1.1} & Golan ve Baron-Cohen, 2006 Deney & $31 \mathrm{E}-10 \mathrm{~K}$ & $17-52$ & AS/YiO & 65 \\
\hline & 1 & $19 E-5 K$ & $17-51$ & OSB'li olmayan & \\
\hline \multirow[t]{2}{*}{1.2} & Golan ve Baron-Cohen, 2006 Deney & $22 E-4 K$ & $17-50$ & OSB & 39 \\
\hline & 2 & $10 E-3 K$ & $17-51$ & OSB'li olmayan & \\
\hline 2 & $\begin{array}{l}\text { Lacava, Golan, Baron-Cohen ve } \\
\text { Smith Myles, } 2007\end{array}$ & $6 \mathrm{E}-2 \mathrm{~K}$ & $12-32$ & AS & 8 \\
\hline 3 & Beaumont ve Sofronoff, 2008 & $44 \mathrm{E}-5 \mathrm{~K}$ & $7-11$ & AS & 49 \\
\hline 4 & $\begin{array}{l}\text { Faja, Aylward, Bernier ve Dawson, } \\
2008\end{array}$ & $10 \mathrm{E}$ & $12-32$ & YiO & 10 \\
\hline 5 & Cheng, Chiang, Ye ve Cheng, 2010 & $3 \mathrm{E}$ & $8-10$ & OSB & 3 \\
\hline 6 & $\begin{array}{l}\text { Tanaka, Wolf, Klaiman, Koenig, } \\
\text { Cockburn, Herlihy, Brown, Stahl, } \\
\text { Kaiser ve Schultz, } 2010\end{array}$ & $62 \mathrm{E}-17 \mathrm{~K}$ & $\begin{array}{c}\text { Deney } \\
\text { Grubu:10.5 } \\
\text { Kontrol } \\
\text { grubu: } \\
11.4\end{array}$ & OSB & 79 \\
\hline 7 & $\begin{array}{l}\text { Lacava, Rankin, Mahlios, Cook ve } \\
\text { Simpson, } 2010\end{array}$ & $4 \mathrm{E}$ & 7-10 & OSB & 4 \\
\hline 8 & Cheng ve Ye, 2010 & $2 \mathrm{E}-1 \mathrm{~K}$ & $7-8$ & OSB & 3 \\
\hline 9 & Lozano, Ballesta ve Alcaraz, 2011 & $9 \mathrm{E}-1 \mathrm{~K}$ & 8-18 & OSB & 10 \\
\hline 10 & $\begin{array}{l}\text { Hopkins, Gower, Perez, Smith, } \\
\text { Amthor, Wimsatt ve Biasini, } 2011\end{array}$ & $\begin{array}{l}23 E-2 K \\
21 E-3 K\end{array}$ & $6-15$ & $\begin{array}{l}\text { YiO } \\
\text { DiO }\end{array}$ & 49 \\
\hline 11 & $\begin{array}{l}\text { Kandalaft, Didehbani, Krawczyk, } \\
\text { Allen ve Chapman, } 2013\end{array}$ & $6 \mathrm{E}-2 \mathrm{~K}$ & $18-26$ & $\begin{array}{c}\text { AS veya BTA- } \\
\text { YGB }\end{array}$ & 8 \\
\hline 12 & Rice, Wall, Fogel ve Shic, 2015 & $28 E-3 K$ & $5-11$ & OSB & 31 \\
\hline 13 & $\begin{array}{l}\text { Thomeer, Smith, Lopata, Volker, } \\
\text { Lipinski, Rodgers, McDonald, ve Lee, } \\
2015\end{array}$ & $38 E-5 K$ & $7-12$ & YiO & 43 \\
\hline
\end{tabular}


AS: Asperger Sendromu, YiO: Yüksek İşlevli Otizm, DiO: Düşük İşlevli Otizm, OSB: Otizm Spektrum Bozukluğu, B: Belirtilmemiş, BTA-YGB: Başka Türlü Adlandırılamayan Yaygın Gelişimsel Bozukluk

İncelenen 13 araştırmanın toplamda 401 katılımcı ile gerçekleştiği görülmektedir. Tablo 1'de belirtildiği gibi katılımcıların cinsiyet özelliklerine göre 338'inin erkek ve 6üçünün kızdan oluştuğu saptanmıştır. Çalışmaya dâhil edilen araştırmaların sadece birinde yaş aralığı belirtilmemiş ve ortalama yaş bilgisine ulaşılmıştır (Tanaka vd., 2010). Diğer araştırmalarda katılımcılara ilişkin yaş bilgileri verilmiştir. Katılımcıların yaş aralıklarına bakıldığında çeşitlilik göstermektedir. Çalışmaların genellikle 5-12, 12-17 ve 17 yaş ve üstü aralıkta toplandığı söylenebilir. Incelenen araştırmaların hiçbirinde erken çocukluk dönemi bireylerle çalışılmamıştır. Ayrıca tüm araştırmalarda katılımcıların almış oldukları tanının OSB (OSB, AS, BTA-YGB) olduğu bulgusuna ulaşılmıştır.

\subsection{Yöntem Özellikleri}

Yöntem özellikleri; hedeflenen sosyal beceri, araştırma modeli, sosyal geçerlilik ve güvenirlik (uygulamacı ve gözlemciler arası güvenirlik) başlıkları altında incelenmiş ve ulaşılan veriler Tablo 2'de sunulmuştur.

3.2.1. Hedeflenen Sosyal Beceri: Araştırma kapsamına dâhil edilen çalışmaların farklı sosyal becerileri hedef aldığı görülmektedir. Ayrıca bir çalışmada birden fazla sosyal becerinin de çalışıldığı saptanmıştır. Dolayısıyla bu araştırmanın temel amacı gereği, bulguların düzenli bir şekilde sunulması amacıyla, çalışılan sosyal beceriler gruplandırılarak verilecektir. Buna göre, incelenen araştırmaların yedisinde yüz tanıma becerisi çalışılmıştır (Golan ve BaronCohen, 2006; Lacava vd., 2007; Beaumont ve Sofronoff, 2008; Faja vd., 2008; Tanaka vd., 2010; Lacava vd., 2010; Hopkins vd., 2011). Bu araştırmalarda yüz tanıma becerisi olarak, kızgınlık, mutluluk, üzgünlük vb. gibi yüz ifadelerini tanımanın yanı sıra Faja ve diğerlerinin (2008), çalışmasında olduğu gibi yüzleri kişiye, yaşa, cinsiyete ve kimliğe göre tanıyabilme becerileri de çalışılmıştır. Araştırmaların yedisinde duyguları tanıyabilme becerisi hedef davranış olarak belirlenmiştir (Golan ve Baron-Cohen, 2006; Lacava vd., 2007; Lacava vd., 2010; Lozano vd., 2011; Hopkins vd., 2011; Kandalaft vd., 2013; Rice vd., 2015). İncelenen çalışmaların altısında etkileşim kurma çalışılmıştır (Beaumont ve Sofronoff, 2008; Lacava vd., 2010; Cheng ve Ye, 2010; Hopkins vd., 2011; Kandalaft vd., 2013; Rice vd., 2015). Etkileşim kurma, araştırmalarda sosyal olarak karşılıklı, olumlu ve olumsuz etkileşim olarak hedeflenmiştir. Araştırmaların ikisinde konuşmayı başlatma, sürdürme, yanıt verme becerilerini içine alan sohbet etme becerisi çalışılmıştır (Beaumont ve Sofronoff, 2008; Rice vd., 2015). Ulaşılan araştırmaların ikisinde zihin kuramının çalışıldığı görülmektedir (Kandalaft vd., 2013; Rice vd., 2015). Ayrıca araştırmalarda çalışılan sosyal becerilere bakıldığında herhangi bir gruba dâhil edilemeyen hedef becerilerde belirlenmiştir. Bunlar; kaygı yönetim stratejilerini kullanma (Beaumont ve Sofronoff, 2008), empati kurabilme (Cheng vd., 2010), davranışları tahmin etme (Lozano vd., 2011), göz kontağı kurabilme, uygun davranışlar gösterme ve karşısındakini dinleyebilme becerilerini içeren sosyal yeterlilik (Cheng ve Ye, 2010), duyguları çözümleme ve kodlama becerileridir (Thomeer vd., 2015).

3.2.2. Araştırma Modeli: Araştırma kapsamında ulaşılan çalışmaların, araştırma modellerine bakıldığında dokuzunun öntest-sontest deneysel desen (Golan ve Baron-Cohen, 2006; Lacava vd., 2007; Faja vd., 2008; Beaumont ve Sofronoff, 2008; Tanaka vd., 2010; Hopkins vd., 2011; Kandalaft vd., 2013; Rice vd., 2015; Thomeer vd., 2015), üçünün tek denekli desen (Cheng vd., 2010; Lacava vd., 2010; Cheng ve Ye, 2010) ve birinin öntest-sontest tek grup deneysel desen (Lozano vd., 2011) kullandıkları görülmektedir. 
Tablo 2.

Yöntem Özellikleri Ile ilgili Bilgiler

\begin{tabular}{|c|c|c|c|c|c|}
\hline No & Yazarlar & Hedeflenen Sosyal Beceri & Araştırma Modeli & Sosyal Geçerlilik & Güvenirlik \\
\hline 1 & $\begin{array}{l}\text { Golan ve Baron- } \\
\text { Cohen, } 2006 \\
\text { Deney } 1 \text { ve } 2\end{array}$ & $\begin{array}{l}\text { Ses ve yüzle ifade edilen karmaşık duyguları } \\
\text { tanımlayabilme. }\end{array}$ & $\begin{array}{l}\text { Öntest-sontest deneysel } \\
\text { desen }\end{array}$ & Katılımcılardan veri toplanmıştır. & $\mathrm{T} / \mathrm{T}$ \\
\hline 2 & $\begin{array}{l}\text { Lacava, Golan, Baron- } \\
\text { Cohen ve Smith } \\
\text { Myles, } 2007\end{array}$ & $\begin{array}{l}\text { Ses ve yüzle ifade edilen karmaşık duyguları } \\
\text { tanımlayabilme. }\end{array}$ & $\begin{array}{l}\text { Öntest-sontest deneysel } \\
\text { desen }\end{array}$ & $\begin{array}{l}\text { Katılımcılardan, öğretmenlerden } \\
\text { ve ebeveynlerden veri } \\
\text { toplanmıştır. }\end{array}$ & UG \\
\hline 3 & $\begin{array}{l}\text { Beaumont ve } \\
\text { Sofronoff, } 2008\end{array}$ & $\begin{array}{l}\text { Karşıııkı olumlu etkileşim, sosyal yanıt verme, } \\
\text { konuşmayı başlatma ve sürdürme, etkileşimli } \\
\text { oyun, vücut duruşu ve yüz ifadelerini anlama, } \\
\text { kızgınlık ve kaygı yönetim stratejilerini bilme. }\end{array}$ & $\begin{array}{l}\text { Öntest-sontest deneysel } \\
\text { desen }\end{array}$ & $\begin{array}{l}\text { Katılımcılardan, öğretmenlerden } \\
\text { ve ebeveynlerden veri } \\
\text { toplanmıştır. }\end{array}$ & $\begin{array}{l}\text { UG } \\
\text { GAG }\end{array}$ \\
\hline 4 & $\begin{array}{l}\text { Faja, Aylward, } \\
\text { Bernier ve Dawson, } \\
2008\end{array}$ & $\begin{array}{c}\text { Yüz tanıma, acil ve ertelemeli yüz hafızası, } \\
\text { ikinci derece ilişkilere duyarlılık, yüzleri yaş, } \\
\text { cinsiyet, grup ve kişisel kimliğe göre } \\
\text { sınıflandırma. }\end{array}$ & $\begin{array}{l}\text { Öntest-sontest deneysel } \\
\text { desen. }\end{array}$ & Ebeveynlerden veri toplanmıştır. & B \\
\hline 5 & $\begin{array}{l}\text { Cheng, Chiang, Ye ve } \\
\text { Cheng, } 2010\end{array}$ & $\begin{array}{l}\text { Nezaket gösterme, tolere etme ve saygı } \\
\text { duyma becerilerinde empati kurabilme. }\end{array}$ & $\begin{array}{l}\text { Yoklama evreli çoklu } \\
\text { yoklama modeli. }\end{array}$ & $\begin{array}{l}\text { Katılımcılardan ve ebeveynlerden } \\
\text { veri toplanmıştır. }\end{array}$ & $\begin{array}{l}\text { UG } \\
\text { GAG }\end{array}$ \\
\hline 6 & $\begin{array}{l}\text { Tanaka, Wolf, } \\
\text { Klaiman, Koenig, } \\
\text { Cockburn, Herlihy, } \\
\text { Brown, Stahl, Kaiser } \\
\text { ve Schultz, } 2010\end{array}$ & Yüz tanıma becerisi. & $\begin{array}{l}\text { Öntest-sontest deneysel } \\
\text { desen }\end{array}$ & B & B \\
\hline
\end{tabular}




\begin{tabular}{|c|c|c|c|c|c|}
\hline No & Yazarlar & Hedeflenen Sosyal Beceri & Araştırma Modeli & Sosyal Geçerlilik & Güvenirlik \\
\hline 7 & $\begin{array}{l}\text { Lacava, Rankin, } \\
\text { Mahlios, Cook ve } \\
\text { Simpson, } 2010\end{array}$ & $\begin{array}{l}\text { Olumlu sosyal etkileşim, ses ve yüzle ifade } \\
\text { edilen karmaşık duyguları tanımlayabilme. }\end{array}$ & $\begin{array}{l}\text { Denekler arası çoklu } \\
\text { başlama deseni. }\end{array}$ & $\begin{array}{l}\text { Okul çalışanlarından ve } \\
\text { ebeveynlerden veri toplanmıştır. }\end{array}$ & $\begin{array}{l}\text { GAG } \\
\text { UG }\end{array}$ \\
\hline 8 & Cheng ve Ye, 2010 & $\begin{array}{l}\text { Sosyal etkileşim, göz kontağı kurabilme, } \\
\text { uygun davranışlar gösterme ve karşısındakini } \\
\text { dinleyebilme. }\end{array}$ & $\begin{array}{l}\text { Denekler arası çoklu } \\
\text { yoklama deseni. }\end{array}$ & $\begin{array}{l}\text { Katılımcılardan ve ebeveynlerden } \\
\text { veri toplanmıştır. }\end{array}$ & $\begin{array}{l}\text { UG } \\
\text { GAG }\end{array}$ \\
\hline 9 & $\begin{array}{l}\text { Lozano, Ballesta ve } \\
\text { Alcaraz, } 2011\end{array}$ & $\begin{array}{l}\text { Temel ve karmaşık duyguları tanımlama ve } \\
\text { doğru veya yanlış inanışlardan yola çıkarak } \\
\text { insanların davranışlarını tahmin etme. }\end{array}$ & $\begin{array}{l}\text { Öntest-sontest tek grup } \\
\text { deneysel desen. }\end{array}$ & $\begin{array}{c}\text { Öğretmenlerden ve } \\
\text { ebeveynlerden veri toplanmıştır. }\end{array}$ & B \\
\hline 10 & $\begin{array}{l}\text { Hopkins, Gower, } \\
\text { Perez, Smith, } \\
\text { Amthor, Wimsatt ve } \\
\text { Biasini, } 2011\end{array}$ & $\begin{array}{l}\text { Yüz tanıma, duyguları tanıma ve sosyal } \\
\text { etkileşim. }\end{array}$ & $\begin{array}{l}\text { Öntest-sontest deneysel } \\
\text { desen }\end{array}$ & $\begin{array}{l}\text { Ebeveynlerden geri dönüt } \\
\text { alınmıştır. }\end{array}$ & GAG \\
\hline 11 & $\begin{array}{l}\text { Kandalaft, Didehbani, } \\
\text { Krawczyk, Allen ve } \\
\text { Chapman, } 2013\end{array}$ & $\begin{array}{l}\text { Etkileşim kurma, duyguları tanıma, zihin } \\
\text { kuramı ve sohbet etme. }\end{array}$ & $\begin{array}{l}\text { Öntest-sontest deneysel } \\
\text { desen }\end{array}$ & $\begin{array}{l}\text { Katılımcılardan telefonla veri } \\
\text { toplanmıştır. }\end{array}$ & G \\
\hline 12 & $\begin{array}{l}\text { Rice, Wall, Fogel ve } \\
\text { Shic, } 2015\end{array}$ & $\begin{array}{c}\text { Duyguları tanıyabilme, karşısındaki kişinin } \\
\text { düşüncelerini anlama, zihin kuramı, olumlu ve } \\
\text { olumsuz etkileşim. }\end{array}$ & $\begin{array}{c}\text { Öntest-sontest deneysel } \\
\text { desen }\end{array}$ & $\begin{array}{l}\text { Öğretmenlerden veri } \\
\text { toplanmıştır. }\end{array}$ & GAG \\
\hline 13 & $\begin{array}{l}\text { Thomeer, Smith, } \\
\text { Lopata, Volker, } \\
\text { Lipinski, Rodgers, } \\
\text { McDonald, ve Lee, } \\
2015\end{array}$ & Duyguları çözümleyebilme ve kodlama. & $\begin{array}{l}\text { Öntest-sontest deneysel } \\
\text { desen. }\end{array}$ & $\begin{array}{l}\text { Ebeveynlerden veri toplanmıştır. } \\
255\end{array}$ & UG \\
\hline
\end{tabular}

B: Belirtilmemiştir, GAG: Gözlemciler Arası Güvenirlik, UG: Uygulama Güvenirliği, T/T: Test/tekrartest 
3.2.3. Sosyal Geçerlilik: İncelenen araştırmaların 1ikisinde sosyal geçerlilik verilerinin toplandığı bulgusuna ulaşılmıştır (Golan ve Baron-Cohen, 2006; Lacava vd., 2007; Beaumont ve Sofronoff, 2008; Faja vd., 2008; Cheng vd., 2010; Lacava vd., 2010; Cheng ve Ye, 2010; Lozano vd., 2011; Hopkins vd., 2011; Kandalaft vd., 2013; Rice vd., 2015; Thomeer vd., 2015). Bir araştırmada ise sosyal geçerlilik verilerine ilişkin bir bilgiye ulaşılamamıştır (Tanaka vd., 2010). Sosyal geçerlilik verilerinin ebeveynlerden, öğretmenlerden, katılımcılardan ve okul çalışanlarından toplandığı saptanmıştır. Veriler, görüşmeler yoluyla veya bu amaçla oluşturulan formlar aracılığıyla toplanmıştır. Incelenen 12 araştırmanın sosyal geçerlilik verilerine bakıldığında yapılan uygulamalara ilişkin olumlu geri dönütler verildiği görülmüştür._Sosyal geçerlilik verilerinde, uygulamaların eğlenceli ve tekrar edilebilir olduğu bulgusuna ulaşılmıştır.

3.2.4. Güvenirlik: BDÖ yönteminin $O S B^{\prime}$ si olan bireylere sosyal beceri öğretimine ilişkin olarak çalışma kapsamında incelenen araştırmaların güvenirlik verileri ile ilgili olarak bazı güvenirlik türleri aranmıştır. Dolayısıyla bu araştırmada, uygulayıcılar arası güvenirlik, gözlemciler arası güvenirlik, test/tekrar test ve uygulama güvenirliği verilerinin bulunup bulunmadığı kapsamlı olarak incelenmiştir. Sözü edilen güvenirlik türleri incelenirken araştırmaların, araştırma modelleri dikkate alınmıştır. Buna göre, incelenen bazı araştırmalarda bir güvenirlik verisine ulaşılırken bazılarında birden fazla veriye ulaşılmıştır. Ancak araştırmaların üçünde güvenirlik ile ilişkili olarak herhangi bir bulguya rastlanmamıştır (Faja vd., 2008; Tanaka vd., 2010; Lozano vd., 2011). Elde edilen bulgulara göre, çalışmaların dördünde hem uygulama güvenirliğine hem de gözlemciler arası güvenirliğe ilişkin verilere ulaşılmıştır (Beaumont ve Sofronoff, 2008; Cheng vd., 2010; Lacava vd., 2010; Cheng ve Ye, 2010). İncelenen araştırmalardan ikisi sadece gözlemciler arası güvenirlik verilerini sunarken (Hopkins vd., 2011; Rice vd., 2015), ikisi sadece uygulama güvenirliğine ilişkin verileri sunmuş (Lacava vd., 2007; Thomeer vd., 2015), biri sadece güvenirlik bilgisi vermiş (Kandalaft vd., 2013) ve araştırmalardan biri ise sadece Test/Tekrar test çalışması yaptığını belirtmiştir (Golan ve BaronCohen, 2006). Araştırmaların güvenirlik verilerine bakıldığında, Golan ve Baron-Cohen (2006)'in güvenirlik verilerinin 81-94 arası (T/T), Beaumont ve Sofronoff (2008)' un 100 (UG) ve 98 (GAG), Lacava ve diğerlerinin (2010) 94.7 (GAG) ve 94.1 (UG), Hopkins ve diğerlerinin (2011), 100 (GAG), Kandalaft ve diğerlerinin (2013), 95 (GAG), Rice ve diğerlerinin (2015), 90 (GAG) ve Thomeer ve diğerlerinin (2015), 98 (UG) olduğu görülmüştür. Diğer araştırmalarda ise güvenirlik yüzdeleri verilmemiştir.

\subsection{Uygulama ve Sonuç Özellikleri}

Uygulamaya ilişkin olarak kullanılan yazıım ve donanım, uygulamanın gerçekleştiği ortam, süre, uygulamanın yapılışı, genelleme çalışmaları ve etkililik durumu ile ilgili verilere Tablo 3'te yer verilmiştir. 
Tablo 3.

Uygulama ve Sonuç Özellikleri Ile Illgili Bilgiler

\begin{tabular}{|c|c|c|c|c|c|c|}
\hline No & Yazarlar & Yazılım/Donanım & Ortam/Süre & Uygulamanın Yapılışı & Genelleme & Etkililik \\
\hline 1 & $\begin{array}{l}\text { Golan ve } \\
\text { Baron- } \\
\text { Cohen, } \\
2006 \\
\text { Deney } 1 \text { ve } \\
2\end{array}$ & $\begin{array}{c}\text { *Mind Reading } \\
\text { *Dizüstü } \\
\text { bilgisayar (15 inç) }\end{array}$ & $\begin{array}{l}\text { *Ev } \\
* 10-15 \text { hafta } \\
\text { boyunca } \\
\text { haftada } 2 \text { saat. }\end{array}$ & $\begin{array}{l}\text { Katılımcılara ses kayıtları, sessiz filmler ve yazılı } \\
\text { örnekleri tanıtılmış ve daha sonra hedeflenen } \\
\text { duyguyu göstermeleri istenmiştir. Uygulama, } \\
\text { oturum açma eğitimi, duygular kütüphanesi ve } \\
\text { oyun alanını da içermektedir. }\end{array}$ & $\begin{array}{l}\text { Üç şekilde genelleme } \\
\text { (yakın, özellik temelli } \\
\text { uzak ve bütünsel uzak } \\
\text { genelleme) çalışması } \\
\text { yapılmıştır ancak } \\
\text { genellemenin } \\
\text { arttırılabilmesi için ek } \\
\text { yöntemlere ihtiyaç } \\
\text { duyulduğu } \\
\text { belirtilmektedir. }\end{array}$ & $\begin{array}{l}\text { Her iki deneyde de deney } \\
\text { grubu kontrol grubundan } \\
\text { dikkate değer bir gelişim } \\
\text { göstermiştir. Ancak } \\
\text { gruplar arasındaki sonuçlar } \\
\text { çok belirgin değildir. }\end{array}$ \\
\hline 2 & $\begin{array}{l}\text { Lacava, } \\
\text { Golan, } \\
\text { Baron- } \\
\text { Cohen ve } \\
\text { Smith } \\
\text { Myles, } \\
2007\end{array}$ & $\begin{array}{l}\text { *Mind Reading } \\
\text { *IBM masaüstü } \\
\text { bilgisayar }\end{array}$ & $\begin{array}{l}\text { *Ev ve okul } \\
\text { *10 hafta } \\
\text { boyunca } \\
\text { haftada bir, } \\
\text { değişken } \\
\text { zamanlı }\end{array}$ & $\begin{array}{l}\text { Yazılım; duygular kütüphanesi, öğrenme merkezi } \\
\text { ve oyun alanını içermektedir. Katılımcılar, } \\
\text { yazılımla etkileşime girebilirler ancak sürenin } \\
\text { \%3üçünü geçmemelidirler. Uygulamada, ekranda } \\
\text { görünen duyguların doğru tanımlanması } \\
\text { gerekmektedir. }\end{array}$ & $\begin{array}{l}\text { Sistematik olmayan } \\
\text { genelleme çalışmaları } \\
\text { rapor edilmektedir. }\end{array}$ & $\begin{array}{l}\text { Araştırma bulgularına göre } \\
\text { hedeflenen becerilerde } \\
\text { uygulanan yöntemin } \\
\text { oldukça etkili olduğu } \\
\text { sonucuna ulaşılmaktadır. }\end{array}$ \\
\hline 3 & $\begin{array}{l}\text { Beaumont } \\
\text { ve } \\
\text { Sofronoff, } \\
2008\end{array}$ & $\begin{array}{l}\text { *Juniour } \\
\text { Detective } \\
\text { Training Program } \\
\text { *B }^{\text {B }}\end{array}$ & $\begin{array}{c}\text { *Üniversite } \\
\text { laboratuvarı } \\
\text { *2 saat ebeveyn } \\
\text { eğitimi ve } 45 \mathrm{dk} \text {. } \\
2 \text { oturum } \\
\text { bilgisayarlı } \\
\text { uygulama ve } 75 \\
\text { dk. } 2 \text { oturum } \\
\text { ebeveyn terapi } \\
\text { zamanı. }\end{array}$ & $\begin{array}{c}\text { Uygulamanın ilk aşamasında bilgisayar } \\
\text { karakterlerinin konuşma özellikleri, vücut } \\
\text { duruşları, yüz ifadeleri katılımcılara öğretilir. İkinci } \\
\text { aşamasında, sözsüz ve çevresel ipuçları } \\
\text { kullanılarak farklı durumlarda karakterlerin } \\
\text { hislerini yorumlamaları öğretilir. Üçüncü } \\
\text { aşamada, çeşitli sanal görevlerde hedeflenen } \\
\text { becerileri uygulama fırsatı verilmektedir. }\end{array}$ & $\begin{array}{l}\text { Genelleme çalışmaları } \\
\text { yapılmıştır ancak } \\
\text { genellemenin bu } \\
\text { yöntem ile sınırlı } \\
\text { olacağı } \\
25 \text { belirtilmektedir. }\end{array}$ & $\begin{array}{l}\text { Yapılan müdahale } \\
\text { hedeflenen becerilerde } \\
\text { etkili olmuştur. Ancak yüz } \\
\text { ifadeleri ve vücut } \\
\text { duruşuna ilişkin bulgularda } \\
\text { anlamlı bir fark olmamıştır. }\end{array}$ \\
\hline
\end{tabular}


Mine KiZiR - Ahmet YIKMIŞ

\begin{tabular}{|c|c|c|c|c|c|c|}
\hline No & Yazarlar & Yazılım/Donanım & Ortam/Süre & Uygulamanın Yapılışı & Genelleme & Etkililik \\
\hline 4 & $\begin{array}{l}\text { Faja, } \\
\text { Aylward, } \\
\text { Bernier ve } \\
\text { Dawson, } \\
2008\end{array}$ & $\begin{array}{l}\text { *MS Powerpoint } \\
\text { ve Adobe } \\
\text { Photoshop } 5.0 \\
\text { *Dizüstü } \\
\text { bilgisayar }\end{array}$ & $\begin{array}{c}\text { *B } \\
\text { *3 hafta } \\
\text { boyunca } 30-60 \\
\text { dakikalık } 8 \\
\text { eğitim oturumu. }\end{array}$ & $\begin{array}{c}\text { Katılımcılara ppt şeklinde yüz fotoğrafları } \\
\text { sunulmuş ve sorular yöneltilmiştir. Doğru cevap } \\
\text { sonrasında tercih ettiği bir resim kısaca } \\
\text { gösterilmiş, yanlış cevaptan sonra doğru cevabın } \\
\text { tekrar sunumu yapılmaktadır. }\end{array}$ & B & $\begin{array}{l}\text { Araştırma sonucunda } \\
\text { ikinci derece ilişkilere } \\
\text { duyarlıık becerisinde iki } \\
\text { grup arasında dikkate } \\
\text { değer bir farklılık } \\
\text { bulunmuştur ancak diğer } \\
\text { becerilerde } \\
\text { bulunmamıştır. }\end{array}$ \\
\hline 5 & $\begin{array}{l}\text { Cheng, } \\
\text { Chiang, Ye } \\
\text { ve Cheng, } \\
2010\end{array}$ & $\begin{array}{l}\text { *Collabrotive } \\
\text { Virtual Learning } \\
\text { Environment } \\
\text { (CVLE)-3D } \\
\text { emphaty system. }\end{array}$ & $\begin{array}{l}\text { *Okul } \\
\text { *Müdahale; } 5 \\
\text { ay süreyle } 22 \\
\text { gün } 6 \text { oturum, } \\
\text { 30-40 dk. }\end{array}$ & $\begin{array}{l}\text { Başlangıçta sistemin nasıl çalıştığıyla ilgili kısa bilgi } \\
\text { verilmektedir. Eğitim süresince katılımcılara } 4 \\
\text { farklı senaryo gösterilmektedir. Bu süreçte } \\
\text { katılımcıya sorular yöneltilmekte ve katılımcı, } \\
\text { kendini temsil eden bir 3D grafik olan avatarı } \\
\text { sayesinde cevap verebilmektedir. }\end{array}$ & $\begin{array}{l}\text { Evde ebeveynlerle } \\
\text { farklı sorular üzerinde } \\
\text { müdahaleye devam } \\
\text { edilerek genelleme } \\
\text { çalışması yapılmıştır. }\end{array}$ & $\begin{array}{l}\text { Uygulamada kullanılan } \\
\text { sistem katılımcıların } \\
\text { empati becerisini } \\
\text { edinmelerinde ve } \\
\text { kalıcılığın sağlanmasında } \\
\text { etkili olmuştur. }\end{array}$ \\
\hline
\end{tabular}

6 Tanaka,

Wolf,

Klaiman,

Koenig,

Cockburn,

Herlihy

bilgisayar

*Let's Face It!

$* \mathrm{~B}$

Kaiser ve

Schultz,

2010
*Ev

*20 saat

tamamlanana

kadar haftada

$100 \mathrm{dk}$.
Katılımcılar hedef becerilere ilișkin 7 oyunu bağımsız bir şekilde oynarlar. 20 saat

tamamlanana kadar katılımcı kendi hızına göre

uygulamayı yapar. Program, motivasyonu sağlamak amacıyla grafikler ve skor kartları sunar.

Ebeveynler araștırmacılardan program hakkında bilgi alabilmektedirler.
Uygulamada kullanılan program yüz tanıma becerisinin

geliştirilmesinde etkili olmuştur. 


\begin{tabular}{|c|c|c|c|c|c|c|}
\hline No & Yazarlar & Yazılım/Donanım & Ortam/Süre & Uygulamanın Yapılışı & Genelleme & 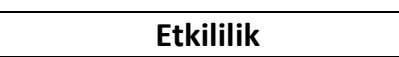 \\
\hline 7 & $\begin{array}{l}\text { Lacava, } \\
\text { Rankin, } \\
\text { Mahlios, } \\
\text { Cook ve } \\
\text { Simpson, } \\
2010\end{array}$ & $\begin{array}{l}\text { *Mind Reading } \\
\text { *Dell bilgisayar }\end{array}$ & $\begin{array}{l}\text { *Okul } \\
\text { *7-10 hafta } \\
\text { boyunca } \\
\text { haftada bir, 1-2 } \\
\text { saat }\end{array}$ & $\begin{array}{l}\text { Yazılımı anlatmak amacıyla katılımcılara yetişkin } \\
\text { bir yardımcı eşlik eder. Yardımcı gerçek hayattaki } \\
\text { duygular hakkında katılımcı ile konuşur, ekrandaki } \\
\text { duyguları doğru tanımlama konusunda yardım } \\
\text { eder. }\end{array}$ & $\begin{array}{c}\text { Genelleme } \\
\text { çalışmalarının sadece } \\
\text { küçük bir katılımcı } \\
\text { grubuyla sınırlı olduğu } \\
\text { belirtilmiş ancak } \\
\text { genelleme } \\
\text { çalışmalarıyla ilgili } \\
\text { ayrıntılı bilgi } \\
\text { verilmemiştir. }\end{array}$ & $\begin{array}{l}\text { Araştırma bulgularına } \\
\text { göre, BDÖ ve yardımcı } \\
\text { akran uygulamasının etkili } \\
\text { olduğu sonucuna } \\
\text { ulaşılmıştır. }\end{array}$ \\
\hline 8 & $\begin{array}{l}\text { Cheng ve } \\
\text { Ye, } 2010\end{array}$ & $\begin{array}{l}\text { *Collabrotive } \\
\text { Virtual Learning } \\
\text { Environment } \\
\text { (CVLE)-3D Social } \\
\text { ineraction system } \\
\text { * Dizüstü } \\
\text { bilgisayar }\end{array}$ & $\begin{array}{l}\text { *Okul } \\
\text { *Haftada } 7 \text { gün } \\
40 \text { dakikalık } \\
\text { oturumlar. }\end{array}$ & $\begin{array}{l}\text { Başlangıçta sistemin nasıl çalıştığıyla ilgili kısa bilgi } \\
\text { verilmiştir. Eğitim süresince katılımcılara } 12 \text { farklı } \\
\text { senaryo gösterilmektedir. Bu süreçte katılımcıya } \\
\text { sorular yöneltilmekte ve katıımcı avatarı } \\
\text { sayesinde cevap verebilmektedir. }\end{array}$ & $\begin{array}{c}\text { Kalıcılık çalışmalarına } \\
\text { ayrıntılı bir şekilde yer } \\
\text { verilmiş ancak } \\
\text { yapılmasına rağmen } \\
\text { genelleme } \\
\text { çalışmalarının } \\
\text { ayrıntıları } \\
\text { verilmemiştir. }\end{array}$ & $\begin{array}{c}\text { Kullanılan sistemin } \\
\text { hedeflenen beceriler } \\
\text { üzerinde olumlu etkisi } \\
\text { olmuştur. }\end{array}$ \\
\hline 9 & $\begin{array}{l}\text { Lozano, } \\
\text { Ballesta ve } \\
\text { Alcaraz, } \\
2011\end{array}$ & $\begin{array}{l}\text { *The educational } \\
\text { software } \\
*_{B}^{B}\end{array}$ & $\begin{array}{l}* \mathrm{~B} \\
* 2 \text { akademik yıl } \\
\text { boyunca } 20 \\
\text { hafta, haftada } \\
45 \mathrm{dk} .\end{array}$ & $*_{\mathrm{B}}$ & $\begin{array}{c}\text { Genelleme } \\
\text { çalışmalarının sadece } \\
\text { katılımcı grubuyla } \\
\text { ş25iglı olduğu belirtilmiş } \\
\text { ancak genelleme } \\
\text { çalışmalarıyla ilgili } \\
\text { ayrıntılı bilgi } \\
\text { verilmemiştir. }\end{array}$ & $\begin{array}{l}\text { Araştırma bulgularına göre } \\
\text { uygulama sonucunda } \\
\text { hedeflenen becerilerde } \\
\text { ilerleme olmuştur. }\end{array}$ \\
\hline
\end{tabular}




\begin{tabular}{|c|c|c|c|c|c|c|}
\hline No & Yazarlar & Yazılım/Donanım & Ortam/Süre & Uygulamanın Yapılışı & Genelleme & Etkililik \\
\hline 10 & $\begin{array}{l}\text { Hopkins, } \\
\text { Gower, } \\
\text { Perez, } \\
\text { Smith, } \\
\text { Amthor, } \\
\text { Wimsatt ve } \\
\text { Biasini, } \\
2011\end{array}$ & $\begin{array}{c}\text { *Face Say } \\
*_{\mathrm{B}}\end{array}$ & $\begin{array}{l}\text { *Okul } \\
\text { *6 hafta } \\
\text { boyunca } \\
\text { haftada } 2 \text { defa } \\
\text { 10-25 dk. }\end{array}$ & $\begin{array}{l}\text { Program, hedeflenen sosyal becerileri öğretmek } \\
\text { amacıyla tasarlanmış bir avatarın bulunduğu } 3 \\
\text { farklı oyundan oluşmaktadır. Oyunlar yap-boz } \\
\text { şeklinde tasarlanmıştır. } 3 \text { parçadan başlayan yap- } \\
\text { boz, katılımcılar ilerledikçe sayısı arttırılmaktadır. } \\
\text { Katılımcılar avatarla etkileşime girerek yüz } \\
\text { parçalarını uygun yüz şekline göre } \\
\text { tamamlamaktadırlar. }\end{array}$ & $\begin{array}{l}\text { Uygulama sonucunda, } \\
\text { katılımcıların edinmiş } \\
\text { oldukları becerileri aile } \\
\text { üyeleri ve akranları ile } \\
\text { doğal ortamlara } \\
\text { genelledikleri ifade } \\
\text { edilmiştir. Ancak farklı } \\
\text { yaş grupları ve farklı } \\
\text { ortamlarda genelleme } \\
\text { çalışmalarına intiyaç } \\
\text { duyulduğu } \\
\text { belirtilmiştir. }\end{array}$ & $\begin{array}{c}\text { Sonuç olarak doğal } \\
\text { ortamda; Yio olan } \\
\text { katılımcılar, duyguları } \\
\text { tanıma ve sosyal etkileşim } \\
\text { alanlarında gelişme } \\
\text { gösterirken, Dio olan } \\
\text { katılımcılar, yüz tanıma, } \\
\text { duyguları tanıma ve sosyal } \\
\text { etkileşim alanlarında } \\
\text { gelişme göstermişlerdir. }\end{array}$ \\
\hline 11 & $\begin{array}{l}\text { Kandalaft, } \\
\text { Didehbani, } \\
\text { Krawczyk, } \\
\text { Allen ve } \\
\text { Chapman, } \\
2013\end{array}$ & $\begin{array}{l}\text { *Virtual Reality } \\
\text { Social Cognition } \\
\text { Training } \\
\text { *Masaüstü } \\
\text { bilgisayar }\end{array}$ & $\begin{array}{l}\text { *Merkez } \\
\text { *5 Hafta } \\
\text { boyunca } 10 \\
\text { oturum. } \\
\text { Haftada } 2 \text { defa } \\
1 \text { saat. }\end{array}$ & $\begin{array}{l}\text { Programda hedeflenen becerilere ilişkin farklı } \\
\text { senaryolar bulunmaktadır. Katılımcı avatarı ve } \\
\text { uygulayııılar senaryolarda birlikte yer alır ve } \\
\text { görevi yerine getirirler. }\end{array}$ & $\begin{array}{l}\text { Genelleme } \\
\text { çalışmalarının, küçük } \\
\text { bir örneklem olması ve } \\
\text { kontrol grubu } \\
\text { olmaması nedeniyle } \\
\text { sınırlı olduğu } \\
\text { belirtilmiştir. }\end{array}$ & $\begin{array}{l}\text { Araştırma sonucunda } \\
\text { hedeflenen beceriler } \\
\text { üzerinde uygulanan } \\
\text { eğitimin etkili olduğu } \\
\text { bulunmuştur. Ayrıca } \\
\text { gerçek hayatta da } \\
\text { becerilerin kullanıldığı } \\
\text { belirtilmiştir. }\end{array}$ \\
\hline 12 & $\begin{array}{l}\text { Rice, Wall, } \\
\text { Fogel ve } \\
\text { Shic, } 2015\end{array}$ & $\begin{array}{l}\text { * FaceSay }^{\mathrm{TM}} \\
{ }^{* \mathrm{~B}}\end{array}$ & $\begin{array}{c}\text { *okul } \\
* 10 \text { hafta } \\
\text { boyunca, } \\
\text { haftada } 1,10-25 \\
\mathrm{dk} .\end{array}$ & $\begin{array}{l}\text { Program, hedeflenen sosyal becerileri öğretmek } \\
\text { amacıyla tasarlanmış } 3 \text { farklı oyundan } \\
\text { oluşmaktadır. Uygulama esnasında katılımcılara } \\
\text { yardımcı olmak için bir yardımcı bulunmaktadır. } \\
\text { Oyunlar çeşitli seviyelerden oluşmaktadır. } \\
\text { Seviyeler kolaydan zora doğru sıralanmıştır. }\end{array}$ & $\begin{array}{l}\text { Öğretmenlerden } \\
\text { edinilen bilgiler } \\
\text { sonucunda } \\
\text { genellemenin sınırlı } \\
\text { olduğu belirtilmiştir. }\end{array}$ & $\begin{array}{c}\text { Araştırma sonucuna göre, } \\
\text { uygulanan yöntem hedef } \\
\text { becerilerin } \\
\text { geliştirilmesinde etkili } \\
\text { olmuştur. }\end{array}$ \\
\hline
\end{tabular}




\begin{tabular}{|c|c|c|c|c|c|c|}
\hline No & Yazarlar & Yazılım/Donanım & Ortam/Süre & Uygulamanın Yapılışı & Genelleme & Etkililik \\
\hline 13 & $\begin{array}{l}\text { Thomeer, } \\
\text { Smith, } \\
\text { Lopata, } \\
\text { Volker, } \\
\text { Lipinski, } \\
\text { Rodgers, } \\
\text { McDonald, } \\
\text { ve Lee, } \\
2015\end{array}$ & $\begin{array}{c}* \text { Mind Reading } \\
*_{\mathrm{B}}\end{array}$ & $\begin{array}{l}\text { *Okul } \\
* 12 \text { hafta } \\
\text { boyunca, } \\
\text { haftada } 90 \\
\text { dakikalık } 2 \\
\text { oturum. }\end{array}$ & $\begin{array}{l}\text { Yazııım; duygular kütüphanesi, öğrenme merkezi } \\
\text { ve oyun alanını içermektedir. Uygulamada, } \\
\text { ekranda görünen duyguların doğru tanımlanması } \\
\text { gerekmektedir. Bunun için katılımcıya yardım } \\
\text { eden bir asistan bulunmaktadır. Oturumlar bire } \\
\text { bir gerçekleşmektedir. Arkasından canlı tekrar } \\
\text { oturumları yapılmaktadır. }\end{array}$ & $\begin{array}{l}\text { Genellemenin } \\
\text { sağlanabilmesi için } \\
\text { oturum ve tekrar } \\
\text { sayısının arttırıldığı } \\
\text { belirtilmiştir. }\end{array}$ & $\begin{array}{l}\text { Araştırma sonuçlarına } \\
\text { göre, uygulanan yöntemin, } \\
\text { duyguları çözümleme ve } \\
\text { kodlama becerilerinin } \\
\text { gelişiminde etkili olduğu } \\
\text { belirtilmiştir. }\end{array}$ \\
\hline
\end{tabular}

B:Belirtilmemiştir 
3.3.1. Yazılım: Örnekleme dâhil edilen araştırmaların bazılarında aynı yazılım programları kullanılırken bazılarında ise farklı türde yazılım programlarının kullanıldığı belirlenmiştir. Araştırmaların dördünde "Mind Reading" yazılım programının kullanıldığı saptanmıştır (Golan ve Baron-Cohen, 2006; Lacava vd., 2007; Lacava vd., 2010; Thomeer vd., 2015). Araştırmaların ikisinde "Collobrative Virtual Learning Environment (CVLE) - 3D Emphaty System" (Cheng vd., 2010; Cheng ve Ye, 2010), ikisinde "FaceSay" (Hopkins vd., 2011; Rice vd., 2015), birinde "Juniour Detective Training Program" (Beaumont ve Sofronoff, 2008), birinde MS Powerpoint ve Adobe Photoshop 5.0" (Faja vd., 2008), birinde "Let's Face It" (Tanaka vd., 2010), birinde "The Educational Software" (Lozano vd., 2011) ve birinde "Virtual Reality Social Cognition Training" (Kandalaft vd., 2013) yazılım programlarının kullanıldığı belirlenmiştir. Yazılım programlarına ilişkin bilgiler Tablo 4'te gösterilmektedir.

Tablo 4.

Yazılım Programları ile ilgili Bilgiler

\begin{tabular}{|c|c|c|}
\hline Yazılım & İçerik & Sistem Gereksinimi (En Az) \\
\hline Mind Reading & $\begin{array}{l}\text { Yazılım, } 412 \text { duyguyu kapsayan duygular } \\
\text { kütüphanesi, öğrenme merkezi ve oyun } \\
\text { alanından oluşan üç uygulamayı } \\
\text { içermektedir. } 5 \text { yaş ve üzeri bireylerin } \\
\text { kullanımı için uygundur. }\end{array}$ & $\begin{array}{l}\text { Pentium 2, } 32 \text { MB RAM, Windows } \\
98 \text { ile çalışır. } \\
800 \text { x } 600 \text { ekran çözünürlüğü ile } \\
\text { 16-bit renkli ekran, ses kartı ve } \\
\text { mikrofona gereksinimi vardır. }\end{array}$ \\
\hline $\begin{array}{l}\text { Collobrative Virtual } \\
\text { Learning Environment } \\
\text { (CVLE)-3D Emphaty } \\
\text { System }\end{array}$ & $\begin{array}{l}\text { Yazılım, 3D teknolojisiyle, restoranda } \\
\text { geçen farklı senaryoları içermektedir. } \\
\text { Katılımcılar animasyon karakterlerden } \\
\text { oluşan avatarlar (sanal insanlar) yoluyla } \\
\text { senaryoya dahil olabilmektedirler. Her } \\
\text { senaryoda duygularla ilgili } 12 \text { soru } \\
\text { bulunmaktadır ve katılımcıdan sözel } \\
\text { olarak cevap vermesi beklenir. }\end{array}$ & $\begin{array}{l}\text { Pentium } 3650 \mathrm{MHZ}, 64 \mathrm{MB} \text { RAM } \\
\text { Windows XP ile çalışmaktadır. }\end{array}$ \\
\hline FaceSay $^{\mathrm{TM}}$ & $\begin{array}{l}\text { Yazılım; Inanılmaz bakış, Yara bandı } \\
\text { kliniği ve Lideri takip etme adlı } 3 \\
\text { etkileşimli oyundan oluşmaktadır. } \\
\text { Oyunlar avatar yardımıyla farklı yüz } \\
\text { ifadelerini tanıma ve göz kontağı kurmayı } \\
\text { amaçlamaktadır. 8-11 yaş arası çocuklar } \\
\text { için uygundur. }\end{array}$ & $\begin{array}{l}\text { Windows XP, Vista, } 7 \text { ve } 2000 \text { ile } \\
\text { çalışmaktadır. } \\
\text { XP ve } 2000 \text { için 1GB; Vista ve } \\
\text { Windows7 için } 2 \mathrm{~GB} \text { hafıza, } 300 \mathrm{MB} \\
\text { boş alan, ses kartı ve mikrofona } \\
\text { gereksinimi vardır. }\end{array}$ \\
\hline Let's Face It & $\begin{array}{l}\text { Yazılım, etkileşimli oyun modüllerini } \\
\text { içermektedir. Modüller yoluyla, göz } \\
\text { kontağı kurma ve yüzle ifade edilen } \\
\text { duygular öğretilmektedir. }\end{array}$ & 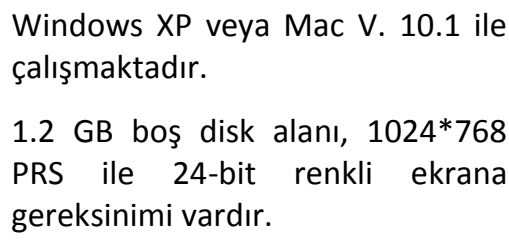 \\
\hline $\begin{array}{l}\text { The Educational } \\
\text { Software }\end{array}$ & $\begin{array}{l}\text { Yazılım, duyguları basitten karmaşığa } \\
\text { doğru öğretebilmek için çeşitli } \\
\text { seviyelerde görevleri içermektedir. }\end{array}$ & Belirtilmemiş \\
\hline
\end{tabular}


Palyaço Zapo yazılımın ana karakteridir

ve yönlendirme yapar.

\begin{tabular}{|c|c|c|}
\hline Yazılım & İçerik & Sistem Gereksinimi (En Az) \\
\hline $\begin{array}{l}\text { Virtual Reality Social } \\
\text { Cognition Training }\end{array}$ & $\begin{array}{l}\text { Second Life programının uyarlanması ile } \\
\text { yazılım geliştirilmiştir. Yazılım, farklı } \\
\text { sosyal ortamlarda, seçilen avatar yoluyla } \\
\text { bulunmayı ve senaryoya uygun sosyal } \\
\text { davranışlar sergilemeyi içermektedir. }\end{array}$ & $\begin{array}{l}\text { Windows XP ile çalışmaktadır. ATI } \\
\text { Radeon } 8500 \text { ekran kartı, } 24 \text { inç } \\
\text { ekran ve } 1920 * 1200 \text { çözünürlüğe } \\
\text { gereksinimi vardır. }\end{array}$ \\
\hline MS Powerpoint & $\begin{array}{l}\text { Yazılım, önceden kaydedilmiş olan } \\
\text { resimleri, metinleri veya sesleri slayt } \\
\text { şeklinde sunabilmektedir. }\end{array}$ & $\begin{array}{l}256 \text { MB RAM, } 1024 * 576 \text { renkli } \\
\text { ekran ile } 1.5 \text { GB disk alanına } \\
\text { gereksinimi vardır. }\end{array}$ \\
\hline Adobe Photoshop 5.0 & $\begin{array}{l}\text { Yazılım, resimler, çizimler ve fotoğraflar } \\
\text { üzerinde değişiklik yapmaya izin } \\
\text { vermektedir. }\end{array}$ & Windows XP ile çalışabilmektedir. \\
\hline
\end{tabular}

3.3.2. Donanım: İncelenen araştırmaların dördünde dizüstü bilgisayar (Golan ve BaronCohen, 2006; Faja vd., 2008; Cheng vd., 2010; Cheng ve Ye, 2010), üçünde masa üstü bilgisayar (Lacava vd., 2007; Lacava vd., 2010; Kandalaft vd., 2013) kullanıldığı saptanmıştır. Ancak araştırmaların, altısında kullanılan donanım ile ilgili herhangi bir bilgiye ulaşılamamıştır (Beaumont ve Sofronoff, 2008; Tanaka vd., 2010; Lozano vd., 2011; Hopkins vd., 2011; Rice vd., 2015; Thomeer vd., 2015).

3.3.3. Ortam: Araştırmaya dâhil edilen çalışmalardan altısında uygulama yeri olarak okul ortamı seçilmiştir (Cheng vd., 2010; Lacava vd., 2010; Cheng ve Ye, 2010; Hopkins vd., 2011; Rice vd., 2015; Thomeer vd., 2015). Uygulamalardan ikisi evde gerçekleşmiştir (Golan ve Baron-Cohen, 2006; Tanaka vd., 2010). Ayrıca araştırmalardan biri hem ev hem de okul ortamında (Lacava vd., 2007), biri merkezde (Kandalaft vd., 2013) ve biri üniversitenin laboratuvarında (Beaumont ve Sofronoff, 2008) gerçekleşmiştir. Incelenen araştırmaların ikisinde uygulamanın yapıldığı ortama ilişkin bir bulguya ulaşılamamıştır (Faja vd. 2008; Lozano vd., 2011).

3.3.4. Süre: Araştırmaların uygulama sürelerinin değişkenlik gösterdiği belirlenmiştir. Bazı çalışmalarda belirli bir sürenin tamamlanması (Tanaka vd., 2010), bazılarında oturum sayıları ve süreleri dikkate alınırken (Beaumont ve Sofronoff, 2008; Cheng vd., 2010; Cheng ve Ye, 2010) bazı çalışmalarda ise belirli hafta sürelerinde, belirli oturum sayıları dikkate alınmıştır (Golan ve Baron-Cohen, 2006; Lacava vd., 2007; Faja vd. 2008; Lacava vd., 2010; Lozano vd., 2011; Hopkins vd., 2011; Kandalaft vd., 2013; Rice vd., 2015; Thomeer vd., 2015). Tanaka ve diğerlerinin (2010) çalışmasında 20 saat tamamlanana kadar haftada 100 dakika uygulama süresi olarak belirlenmiş, oturum süresi veya hafta sayısı zorunlu tutulmamıştır. Süre katılımcıların tercihine bırakılmıştır. İncelenen araştırmalar arasında hafta olarak en uzun süre iki akademik yıl boyunca 20 hafta ve haftada 45 dakika ile Lozano ve diğerlerinin (2011) çalışmasıdır. En kısa çalışma ise üç hafta boyunca 30-60 dakikalık sekiz eğitim oturumu ile Faja ve diğerlerinin (2008) çalışmasıdır.

3.3.5. Uygulama: Örnekleme dâhil edilen araştırmaların uygulama bakımından benzerlik gösterdiği söylenebilir. Uygulamaların yapılışına ilişkin bilgiler Tablo 2'de sunulmaktadır. Bu bilgilere bakıldığında araştırmalardan dördünde avatar yardımı ile sosyal becerilerin öğretildiği görülmektedir (Hopkins vd., 2011; Kandalaft vd., 2013; Cheng vd., 2010; Cheng ve Ye, 2010). Araştırmaların dördünde BDÖ uygulaması esnasında katılımcıya bir 
yardımcının eşlik ettiği bulgusuna ulaşılmıştır (Faja vd. 2008; Lacava vd., 2010; Rice vd., 2015; Thomeer vd., 2015). Incelenen araştırmaların birinde hem avatar hem de bir yardımcı bulunmaktadır (Kandalaft vd., 2013). Diğer araştırmaların uygulamalarında katılımcılara ön bir eğitim verilerek programdaki hedefleri tamamlamaları istenmiştir. Lozano ve diğerlerinin (2011) çalışmasında ise uygulamanın yapılışına ilişkin bir bilgiye rastlanmamıştır.

3.3.6. Genelleme: OSB'li olan bireylere sosyal beceri öğretimini hedef alan ve araştırma kapsamına dâhil edilen çalışmaların genelleme verilerine ilişkin sunulan bilgiler bazı araştırmalarda ayrıntılı olarak verilmiş ancak bazı araştırmalarda genelleme oturumları, türleri (kişi, ortam, zaman), kayıt yöntemine ilişkin ayrıntılı bir veriye ulaşılamamıştır. İncelenen araştırmaların 1birinde genelleme çalışmalarının yapıldığı ancak sınırlı olduğu veya ek çalışmalarla desteklenmesi gerektiği belirtilmiştir (Golan ve Baron-Cohen, 2006; Lacava vd., 2007; Beaumont ve Sofronoff, 2008; Cheng vd., 2010; Cheng ve Ye, 2010; Lacava vd., 2010; Lozano vd., 2011; Hopkins vd., 2011; Kandalaft vd., 2013; Rice vd., 2015; Thomeer vd., 2015). Araştırmaların ikisinde ise genelleme verilerine ilişkin bilgilere ulaşılamamıştır (Faja vd. 2008; Tanaka vd., 2010). Incelenen araştırmalara bakıldığında genelleme çalışmalarına ilişkin ayrıntılı bilgiye Golan ve Baron-Cohen (2006)'in araştırmasında ulaşılmıştır. Bu araştırmada üç şekilde genelleme çalışması yapılmıştır; (1) farkı bir yazııımın kullanıldığı genelleme, (2) uygulama esnasında kullanılmayan ses ve yüzlerin kullanıldığı özellik temelli genelleme ve (3) farklı senaryolarda filmleri içeren bütünsel olarak gerçekleştirilen genelleme çalışmaları yapılmıştır, ancak genellemenin arttırılabilmesi için ek yöntemlere ihtiyaç duyulduğu belirtilmiştir. Lacava ve diğerleri (2007)'nin çalışmalarında uygulama esnasında kullanılan yazılımda olmayan ses ve yüz materyalleriyle genelleme çalışmaları yapılmış ve hedef davranışlar doğal ortamlarda gözlenmiştir. Beaumont ve Sofronoff (2008), ev ödevleri ve akranlarla oyun etkinlikleri ile genelleme çalışmalarını gerçekleştirmişlerdir. Diğer araştırmalarda kişi, ortam veya zaman genellemesine yönelik ayrıntılı bir bulguya ulaşılamamıştır. Araştırmalarda bu durum "sınırlı genelleme çalışmaları" olarak ifade edilmiştir. Tüm araştırmaların genelleme bulgularına bakıldığında, yapılan çalışmalar dâhilinde katılımcıların hedeflenen becerileri genelleyebildikleri ancak ek genelleme çalışmalarına gereksinim olduğu görülmüştür.

3.3.7. Etkililik: Örneklem grubuna dâhil edilen araştırmaların OSB'li bireylere sosyal beceri öğretiminde BDÖ'nün etkililiğini belirlemek amacıyla uygulamalar yapmış oldukları görülmektedir. Yapılan tüm uygulamaların, araştırmalarda hedeflenen sosyal becerileri edindirmede etkili oldukları bulgusuna ulaşılmıştır. Araştırmaların etkililiklerine ilişkin ortalamalar Tablo 5'te gösterilmektedir.

Tablo 5.

incelenen Araştırmaların Etkililik Verileri

\begin{tabular}{llll}
\hline \multicolumn{1}{c}{ Yazarlar } & Öntest/Başlangıç düzeyi & Sontest/Müdahale \\
\hline $\begin{array}{l}\text { Golan ve } \\
\text { Deney } 1\end{array}$ & Baron-Cohen, 2006 & Yüz tanıma: 32.5 & Yüz tanıma: 34.8 \\
& & Ses tanıma: 35.2 & Ses tanıma: 36.6 \\
& & & Yüz tanıma: 29.3 \\
$\begin{array}{l}\text { Golan ve } \\
\text { Deney } 2\end{array}$ & Baron-Cohen, 2006 & Yüz tanıma: 26.8 & Ses tanıma: 31.8 \\
& & Ses tanıma: 31.1 & \\
\hline
\end{tabular}


Lacava, Golan, Baron-Cohen ve Yüz tanıma: 28.375

Smith Myles, 2007

Beaumont ve Sofronoff, 2008

Tanaka, Wolf, Klaiman, Koenig, Cockburn, Herlihy, Brown, Stahl, Kaiser ve Schultz, 2010

Cheng, Chiang, Ye ve Cheng, 2010

Faja, Aylward, Bernier ve Dawson, 2008

Lacava, Rankin, Mahlios, Cook ve Simpson, 2010

Cheng ve Ye, 2010

Lozano, Ballesta ve Alcaraz, 2011

Hopkins, Gower, Perez, Smith, Amthor, Wimsatt ve Biasini, 2011

Adam: 4.67

Luke: 5.75

James: 5.00

Yüz hafızası: 43.1

Kimlik eşleme:52.1

ifadeler: 56.4

Yüzü tanıma: 58.3

\author{
Ses tanıma: 29.875
}

Sosyal beceriler: 25.30

Duyguları yönetme ve sosyal beceriler: 39.78

Yüz ifadeleri: 17.44

Vücut duruşu: 20.48
Yüz tanıma: 33.750

Ses tanıma: 32.750

Sosyal beceriler: 38.08

Duyguları yönetme ve sosyal

beceriler:57.38

Yüz ifadeleri: 19.92

Vücut duruşu: 21.81

\section{Sontest/Müdahale}

İkincil düzey ilişkiler: 85

Uygulama hedeflenen diğer becerilerde etkili olmamıştır.

Adam: 11.66

Luke: 11.87

James: 10.34

Yüzün boyutları: 72.1

Yüzün boyutları: 79.8

Yüz hafızası: 43

Kimlik eşleme: 58.1

ifadeler: 59.2

Yüz tanıma: 64.1

Sosyal etkileşim grup: 30.4

Sosyal yeterlilik: 45.3

Sosyal yeterlilik:76

Test sonuçları verilmemiştir.

Duygu ve yüz tanıma (DiO):5.43

Duygu ve yüz tanıma (DiO):6.57

Duygu ve yüz tanıma (YiO):8.00

İşbirliği (DiO):6.43

Duygu ve yüz tanıma (YiO):9.54

İşbirliği (DiO):8.14

İşbirliği (YiO):6.36

İşbirliği (YiO):6.73

Hakkını arama (DiO):6.93

Hakkını arama (DiO):7.93

Hakkını arama (YiO):7.00

Hakkını arama (YiO):7.82

Sorumluluk (DiO):4.07

Sorumluluk (DiO):5.36

Sorumluluk (YIO):4.82 
Otizm Spektrum Bozukluğu Olan Bireylere Sosyal Beceri Öğretiminde Bilgisayar Destekli Öğretim Uygulamalarının Gözden Geçirilmesi

Mine KiZiR - Ahmet YIKMIŞ

\begin{tabular}{|c|c|c|}
\hline \multirow{5}{*}{$\begin{array}{l}\text { Kandalaft, Didehbani, Krawczyk, } \\
\text { Allen ve Chapman, } 2013\end{array}$} & Kendini kontrol (DiO):5.71 & Kendini kontrol (DiO):7.57 \\
\hline & Kendini kontrol (YiO):4.64 & Kendini kontrol (YiO):6.54 \\
\hline & $\begin{array}{l}\text { Sosyal algı (Her katılımcı için:K) : } \\
\mathrm{K} 1 ; 9, \mathrm{~K} 2 ; 9, \mathrm{~K} 3 ; 4, \mathrm{~K} 4 ; 3, \mathrm{~K} 5 ; 6, \mathrm{~K} 6 ; 8 \text {, } \\
\mathrm{K} 7 ; 14, \mathrm{~K} 8 ; 8\end{array}$ & $\begin{array}{l}\text { Sosyal algı (Her katılımcı için:K) : } \\
\mathrm{K} 1 ; 13, \mathrm{~K} 2 ; 10, \mathrm{~K} 3 ; 5, \mathrm{~K} 4 ; 3, \mathrm{~K} 5 ; 9 \text {, } \\
\mathrm{K} 6 ; 12, \mathrm{~K} 7 ; 13, \mathrm{~K} 8 ; 12\end{array}$ \\
\hline & $\begin{array}{l}\text { Zihin kuramı (Her katılımcı için:K) } \\
\text { : K1;15, K2;13, K3;6, K4;6, K5;15, } \\
\text { K6;21, K7;12, K8;13 }\end{array}$ & $\begin{array}{l}\text { Zihin kuramı (Her katılımcı için:K) } \\
\begin{array}{l}\text { : K1;20, K2;15, K3;9, K4;11, } \\
\text { K5;13, K6;24, K7;16, K8;15 }\end{array}\end{array}$ \\
\hline & $\begin{array}{l}\text { Etkileşim kurma (Her katılımcı } \\
\text { için:K) : K1;74, K2;53.5, K3;50.5, } \\
\text { K4;55, K5;70.5, K6;66, K7;65, } \\
\text { K8;69 }\end{array}$ & $\begin{array}{l}\text { Etkileşim kurma (Her katılımcı } \\
\text { için:K): K1;78, K2;62.5, K3;59, } \\
\text { K4;52.5, K5;68.5, K6;71.5, } \\
\text { K7;67.5, K8;72 }\end{array}$ \\
\hline Yazarlar & Öntest/Başlangıç düzeyi & Sontest/Müdahale \\
\hline \multirow[t]{2}{*}{ Rice, Wall, Fogel ve Shic, 2015} & Olumsuz duyguları tanıma: 8.63 & Olumsuz duyguları tanıma: 12.56 \\
\hline & Zihin Kuramı: 15.38 & Zihin Kuramı: 21.63 \\
\hline \multirow{4}{*}{$\begin{array}{l}\text { Thomeer, Smith, Lopata, Volker, } \\
\text { Lipinski, Rodgers, McDonald, ve } \\
\text { Lee, } 2015\end{array}$} & Yüz tanıma:23.05 & Yüz tanıma:32.71 \\
\hline & Sesleri tanıma:22.95 & Sesleri tanıma:30.95 \\
\hline & Duyguları anlama:93.45 & Duyguları anlama:119.50 \\
\hline & Duyguları ifade etme:107.64 & Duyguları ifade etme:130.59 \\
\hline
\end{tabular}

Tablo 5'e bakıldığında tüm araştırmalarda uygulanan BDÖ yönteminin hedeflenen beceriler üzerinde etkili olduğu sonucuna varılmaktadır. Araştırmalardan Faja ve diğerlerinin (2008), çalışmasında uygulama ikincil düzey ilişkileri tanıyabilmede etkili olmasına rağmen hedeflenen diğer becerilerde etkili olmadığı görülmektedir. Ek olarak, Beaumont ve Sofronoff (2008)'un çalışmalarında yüz ifadeleri ve vücut duruşuna ilişkin bulgularda anlamlı bir fark olmadığı belirtilmektedir. Ayrıca Lozano ve diğerlerinin (2011), çalışmalarında sayısal bir veriye ulaşılamamaktadır.

\section{SONUÇ, TARTIŞMA VE ÖNERILER}

$\mathrm{Bu}$ araştırma, bilimsel dayanaklı bir uygulama olan BDÖ'nün, OSB'li bireylere sosyal beceri öğretimindeki etkililiğini konu alan, 2005-2015 yılları arasında yayımlanan araştırmaların betimlenmesi amacıyla gerçekleştirilmiştir. Bu amaçla 13 araştırma incelenmiş ve belirlenen ölçütler doğrultusunda analizleri gerçekleştirilmiştir. Bu bölümde analizler sonucunda elde edilen bulgular, ilgili alan yazınla desteklenerek tartışılacaktır.

Incelenen 13 araştırmanın katılımcı özellikleri bakımından en belirgin olan durumu, katılımcıların yaş özellikleridir. Çalışmaların genellikle 5-12, 12-17 ve 17 yaş ve üstü aralıkta toplandığı bulgusu saptanmıştır. Görüldüğg̈u gibi araştırmaların hiçbirinde 5 yaş ve altı çocuklarla çalışımamıştır. Bunun nedeninin erken çocukluk ve okul öncesi dönemi çocuklarının psiko-motor gelişimlerini tamamlamamış olmalarından kaynaklandığı düşünülmektedir. OSB'li çocukların motor becerilerdeki performanslarını inceleyen araştırmalara bakıldığında bu çocukların özellikle el-göz koordinasyonu ve el becerisi gerektiren etkinliklerde akranlarından düşük performans gösterdikleri bulgusuna ulaşıldığı görülmektedir (Piek ve Dyck, 2004; Günal 
ve Bumin, 2007). Dolayısıyla, beş yaş altı OSB'li çocukların fare ve klavye gibi bilgisayar girdi aygıtlarını kullanmada güçlük yaşadıkları düşünülebilir. Bu durum BDÖ’nün okul öncesi çocuklara uygulanmasını güçleştirebilmektedir. Bu nedenle incelenen araştırmalarda daha çok katılımcı olarak ergenlik ve yetişkinlik dönemlerindeki bireylerin tercih edildiği söylenebilir. Ancak sosyal becerilerin öğretilmesine daha erken yaşlarda başlanması gerekliliği göz önünde bulundurulduğunda, bu durumun BDÖ kullanımını, okul öncesi dönem OSB'li çocuklarda sınırlandırdığını düşündürmektedir.

Araştırma kapsamına dâhil edilen çalışmalarda hedeflenen sosyal becerilere bakıldığında daha çok yüz ve duyguları tanıma ve etkileşimde bulunma becerilerinin çalışıldığı görülmektedir. OSB'li bireylerin sosyal becerilerdeki yetersizlikleri dikkate alındığında, yüz ve duyguları tanıma gibi temel becerilerin hedef alınması daha karmaşık sosyal becerilerin edinimi için bir basamak oluşturacaktır. BDÖ'de kullanılan yazılım programları, bu becerilerin hedef alınması ve OSB'li bireylere öğretimi için daha elverişli olmaktadır. Bu yazılımlar sayesinde, uygun sosyal davranışları edinen bireylerin sanal ortamlardan gerçek, doğal ortamlara geçişlerinin daha kolay olabilmektedir (Parsons ve Mitchell, 2002; Cheng ve diğ., 2010).

Yapılan bir araştırmanın başarılı sayılmasının vazgeçilmez ölçütlerinde biri sosyal kabulünün ya da geçerliğinin değerlendirilmesidir (Vuran ve Sönmez, 2008). Sosyal geçerlik, uygulanan programın; amacına ve bu amaca ulaşmak için kullanılan yöntemlerin uygunluğuna ve elde edilen bulguların önemine ve programın etkilerine ilişkin doğrudan çalışmaya katılan kişilerin kendilerinden veya bu kişilerin yaşamındaki, ebeveyn ya da öğretmen gibi önemli kişilerden görüş alınmasıdır. Güvenirlik ise, "Bir değerin bağımsız ölçümler sonucunda gösterdiği kararlılıktır" (Sucuoğlu vd., 2010, s. 49,80). Özellikle nicel araştırmalarda bu kavramlar araştırmanın bilimselliğini belirlemekte oldukça etkilidir. Araştırmacıların, kullandığı veri toplama araçlarını, araştırma yönteminin geçerliliğini ve güvenirliğini özenli ve dikkatli bir şekilde değerlendirmeleri ve sonuçları rapor etmeleri beklenir (Yıldırım ve Şimşek, 2008). Sosyal geçerlik, özellikle sosyal becerilerin hedef alındığı araştırmalarda büyük bir önem taşımaktadır. İncelenen araştırmaların geçerlik ve güvenirlik çalışmalarına bakıldığında büyük çoğunluğunun bu verileri ayrıntılı bir şekilde sundukları söylenebilir. Araştırmalara bakıldığında sosyal geçerlilik verilerinin bazılarında katılımcıların kendilerinden bazılarında ise katılımcıların birebir etkileşim halinde oldukları ebeveynleri veya öğretmenlerinden toplandığı görülmektedir. Uygulanan programlara ilişkin yapılan geri dönütler oldukça olumludur. Bu bulgular ışığında, BDÖ’nün sosyal geçerliliği yüksek bir yöntem olduğu söylenebilir. Araştırmalarda katılımcılardan veri toplanmasının, katılımcı yaşlarının ergenlik ve yetişkinlik evrelerini içine alması ve bireylerin uygulamaya ilişkin görüş bildirebilecek olgunlukta olmaları bir neden olarak görülmektedir. Geçerlik ve güvenirlik verilerinin belirtilmediği araştırmaların bilimsellik anlamında yetersiz oldukları düşünülmektedir.

Incelenen araştırmalarda kullanılan yazııı programlarının genellikle benzer şekilde tasarlandığı görülmektedir. Bu programlar, çeşitli bölümler ve seviyelerden oluşmaktadır. Programların bir bölümünde katılımcılara oyun etkinlikleri sunulmuş veya bölümler bir bilgisayar oyunu şeklinde tasarlanmıştır (Golan ve Baron-Cohen, 2006; Lacava ve diğ., 2007; Tanaka ve diğ., 2010; Hopkins ve diğ., 2011; Rice ve diğ., 2015; Thomeer ve diğ., 2015). Bu durum katılımcıların, uygulamaya katılımlarını ve devamlarını teşvik edici bir özellik olmuştur. Günümüzde pek çok bireyin bilgisayar oyunlarına karşı ilgileri göz önünde bulundurulduğunda, bu özelliği BDÖ’nün bir avantajı olmaktadır. Ayrıca uygulama ortamlarının genellikle okul veya ev ortamında yapıldığı görülmektedir. BDÖ uygulamalarının sanal ortamda gerçekleşmesi nedeniyle uygulama ortamının araştırma sonucunu etkilemediği düşünülmektedir. Ancak genelleme çalışmalarının yapılandııımış veya sanal ortamlarda değil doğal ortamlarda yapılması gerekmektedir. Bu şekilde edinilen becerilerin genellenmesi de sağlanabilir. Ek olarak 
araştırmaların uygulamanın yapıldığı süre ve yoğunluk bakımından değişiklik gösterdiği bulgusuna ulaşılmıştır. Bu durumun hedeflenen sosyal becerilerin çeşitliliği ile ilişkili olduğu düşünülebilir.

Araştırma kapsamında analizi yapılan çalışmaların, uygulamalarına bakıldığında kullanılan yazılım programları bakımından benzer özellikler taşıdıkları görülmektedir. Uygulamaların bazı araştırmalarda avatar kullanılarak yapıldığı belirlenmiştir. Bu avatarlar OSB'li bireylerin sanal ortamlarda uygun sosyal davranışlar göstermelerine yardımcı olmaktadırlar. Yine bazı araştırmalarda sanal ortamda oluşturulan senaryolar sayesinde katılımcıların sosyal ortamların benzerlerini tanıyarak uygun davranışları göstermeleri mümkün olmaktadır. Bazı uygulamalarda ise yüz ve duyguları tanımaya yardımcı olan yazılım programları farklı pek çok yüz şeklini, ifadelerini ve duyguları tanıma fırsatı sağlamaktadır. Bu uygulamaların daha öncede belirtildiği gibi ilgi çekici oyunlar ve farklı seviyelerde programların tamamlanması ile uygulamaların yapılıyor olması, BDÖ yönteminin OSB'li bireylere sosyal beceri öğretiminde kullanılmasının olumlu bir yanını oluşturmaktadır.

Uygulanacak bir yöntemin bireyin yaşam kalitesi ve iyi oluşu açısından işlevsel olabilmesi için sadece okul, sınıf, kantin, bahçe gibi eğitim ortamlarında ve uzmanlar tarafından sunulması değil farklı ortamlarda, farklı kişiler tarafından, farklı zamanlarda ve faklı durumlarda da sunulabilmesi ve işlevsel olması önemlidir (Toper-Korkmaz, 2012). Bu nedenle araştırmacıların bir araştırmayı planlarken genelleme çalışmalarına da yer vermeleri gerekmektedir. Sucuoğlu ve diğerleri $(2010$, s. 46) genelleme kavramını, "Daha önce bir durum/ bir ortamda öğrenilmiş bilgi veya becerilerin orijinal olarak öğrenildiğinden farklı olan durumlarda ortaya çıkması ve işlevsel olarak sergilenmesidir. Başka bir deyişle öğrenilenleri diğer ortamlara, çevreye, zamana ve olaylara göre uyarlama, transfer etme becerisidir" şeklinde tanımlamaktadırlar. Tanımdan da anlaşılacağı gibi OSB'li bireyler için sosyal becerileri farklı ortamlara, çevreye, zamana, olaylara ve kişilere göre genellemenin oldukça zor olduğu söylenebilir. Akranlar yerine öğretmen veya uygulayıcıların olduğu, doğal olmayan ortamlarda ve belirli davranışları hedef alan sosyal beceri öğretim programları, çocuk tarafından öğrenilmiş olan sosyal becerilerin aktarılmasında ve genellenmesinde sorunlara neden olabilmektedir (Avcıoğlu, 2012). BDÖ’nün doğası gereği, gerçek ortamlar da değil sanal ortamlarda sosyal beceri öğretiminin yürütülmesi nedeniyle, uygulamalarda öğrenilen sosyal becerilerin mutlaka doğal ortamlarda da genelleme çalışmalarının yapılması gerekmektedir. İncelenen araştırmalarda, genelleme çalışmalarının yapıldığı ancak katılımcıların bulundukları her ortamda, etkileşime girdikleri her kişiyle ve farklı zamanlarda yürütülmesinin zor olması nedeniyle sınırlı olduğu vurgusu yapılmıştır. Genelleme, BDÖ dışında ki diğer yöntemler için de problem olmaktadır. (Hopkins vd, 2011). Genellemeye ilişkin problemin çözümünde, verilen eğitime, aile ve okul çalışanlarının da dâhil edilmesinin etkili olabileceği düşünülmektedir. Bu şekilde edinim aşamasından sonra çocuk tarafından öğrenilen becerinin genellenmesinde aile ve okul çalışanları, aldıkları eğitim sayesinde farklı durumlara ve koşullara çocuğun beceriyi transfer edebilmesine yardımcı olabileceklerdir.

Incelenen tüm araştırmaların, hedeflenen sosyal becerilerin öğretiminde etkili olduğu belirlenmiştir. Ayrıca genelleme çalışmalarının yapıldığı araştırmalarda, sınırlı olmasına rağmen öğrenilen becerilerin genellenebildiği de ifade edilmektedir.

OSB'li bireylerin, sosyal etkileşim için gerekli sözel olmayan davranışlarda yetersizlik, yaşa uygun ve akran ilişkileri geliştirememek, başkalarıyla zevk, başarı ya da paylaşımında sınırlıık, sosyal-duygusal davranışlarda sınırlılıkları içeren sosyal etkileşim sorunları yaşadıkları bilinmektedir (Kırcaali-iftar, 2007, s. 19-22). OSB'li bireylerin, bu alanda yaşadıkları güçlükleri aşmada uygulanan pek çok yöntem mevcuttur. Bilimsel dayanaklı bir yöntem olan BDÖ, incelenen araştırmalar ışığında OSB'li bireylere, sosyal beceri öğretiminde etkili bir yöntemdir. 
$\mathrm{Bu}$ yöntemin ülkemizde kullanılabilmesi için Türk kültürüne, iletişim biçimine, eğitim sistemine... vb. gibi konulara uygun yazılım programları geliştirilmesine ihtiyaç duyulmaktadır. Ayrıca bugüne kadar geliştirilmiş olan programların da daha geniş kitlelere ulaşması için çalışmalar yapılması gerekmektedir.

Ileriki çalışmalarda genelleme çalışmalarına daha fazla yer verilerek raporlamanın ayrıntılı bir şekilde yapılması araştırmacılara yol gösterici olacaktır. Yapılacak olan çalışmaların okulöncesi çocukları da kapsaması önerilmektedir. Ek olarak BDÖ'nün diğer yetersizlik grupları için de çalışılmasının onların gelişimlerinde yararlı olacağı düşünülmektedir.

\section{KAYNAKLAR}

Alkan, C. (1998). Eğitim teknolojisi. Ankara: Anı Yayıncılık

American Psychiatric Association. (2013). Diagnostic and statistical manual of mental disorders (dsm-v): amerikan psikiyatri birliği, dsm 5 tanı ölçütleri başvuru el kitabı. E. Köroğlu (Çev.). Ankara: Boylam Psikiyatri Enstitüsü Hekimler Yayın Birliği.

Avcıoğlu, H. (2012). Zihinsel yetersizliği olan çocuklara sosyal beceri kazandırmada işbirliğine dayalı öğrenme ve drama yöntemlerinin etkililiği. Eğitim ve Bilim, 37(163).

Bayram, S. (2006). Bilgisayar destekli özel eğitim. 2. İstanbul Otizm Eğitimi Günleri.

Beaumont, R., \& Sofronoff, K. (2008). A Multi-component social skills intervention for children with asperger syndrome: the junior detective training program. Journal of Child Psychology and Psychiatry, 49(7), 743-753.

Boucher, J., Mayes, A., \& Bigham, S. (2008). Memory, language and intellectual ability in lowfunctioning autism.

//FS2/CUP/3-PAGINATION/BBM/2-

Boucher, J., Bigham, S., Mayes, A., \& Muskett, T. (2008). Recognition and language in low functioning autism. Journal of Autism and Developmental Disorders, 38(7), 1259-1269.

Cheng, Y., Chiang, H. C., Ye, J., \& Cheng, L. H. (2010). Enhancing empathy instruction using a collaborative virtual learning environment for children with autistic spectrum conditions. Computers \& Education, 55(4), 1449-1458.

Cheng, Y., \& Ye, J. (2010). Exploring the social competence of students with autism spectrum conditions in a collaborative virtual learning environment-the pilot study. Computers \& Education, 54(4), 1068-1077.

Demirel, Ö., Seferoğlu, S.S. ve Yağcl, E. (2003). Öğretim teknolojileri ve materyal geliştirme (4. Basım). Ankara: Pegem Yayıncılık

Doğan, T. (2003). Öğretmen ve eğitim yöneticilerine rehber. Ankara: Seçkin Yayıncılık

Doğan, í. ve Akdemir, Ö. (2015). Özel eğitimde bilgisayar destekli öğretim: üç durum çalışması. Yüksekögrretim ve Bilim Dergisi/Journal of Higher Education and Science. Cilt/Volume 5, Sayı/Number 2, Sayfa/Pages 165-177

Faja, S., Aylward, E., Bernier, R., \& Dawson, G. (2007). Becoming a face expert: a computerized face-training program for high-functioning individuals with autism spectrum disorders. Developmental Neuropsychology, 33(1), 1-24.

Günal, A. ve Bumin, G. (2007). Otistik çocuklarda motor performansın incelenmesi. Fizyoterapi Rehabilitasyon. 18(3):179-186 
Golan, O., \& Baron-Cohen, S. (2006). Systemizing empathy: Teaching adults with asperger syndrome or high-functioning autism to recognize complex emotions using interactive multimedia. Development and Psychopathology,18(02), 591-617.

Halis, ì. (2001). Öğretim Teknolojileri ve materyal geliştirme. Konya: Mikro Yayınları

Hetzroni, O. E., \& Tannous, J. (2004). Effects of a computer-based intervention program on the communicative functions of children with autism. Journal of Autism and Developmental Disorders, 34(2), 95-113.

Hopkins, I. M., Gower, M. W., Perez, T. A., Smith, D. S., Amthor, F. R., Wimsatt, F. C., \& Biasini, F. J. (2011). Avatar assistant: Improving social skills in students with an asd through a computer-based intervention. Journal of Autism and Developmental Disorders, 41(11), 1543-1555.

Kandalaft, M. R., Didehbani, N., Krawczyk, D. C., Allen, T. T., \& Chapman, S. B. (2013). Virtual reality social cognition training for young adults with high-functioning autism. Journal of Autism and Developmental Disorders, 43(1), 34-44.

Karasu, N. (2009). Otizmden etkilenmiş bireylerde sosyal ve iletişim becerilerini arttıran yöntemlerin delile dayalı yöntem olarak belirlenmesi: Bir meta-analiz örneği. Türk Eğitim Bilimleri Dergisi, 7(3).

Kırcaali-iftar, G. (2007). Otizm spektrum bozukluğu. İstanbul: Daktylos Yayınları

Lacava, P. G., Golan, O., Baron-Cohen, S., \& Myles, B. S. (2007). Using assistive technology to teach emotion recognition to students with asperger syndrome a pilot study. Remedial and Special Education, 28(3), 174-181.

Lacava, P. G., Rankin, A., Mahlios, E., Cook, K., \& Simpson, R. L. (2010). A Single case design evaluation of a software and tutor intervention addressing emotion recognition and social Interaction in four boys with ASD. Autism: The International Journal of Research and Practice, 14(3), 161-178.

Lozano Martínez, J., Ballesta Pagán, J., \& Alcaraz García, S. (2011). Software for teaching emotions to students with Autism Spectrum Disorder. Scientific Journal of Media Litreracy. Comunicar, 36. XVIII

Luiselli, J. K. (2014). Children and Youth with Autism Spectrum Disorder (ASD): Recent Advances and Innovations in Assessment, Education, and Intervention. Oxford University Press, USA.

MEB. (2013). Çocuk gelişimi ve eğitimi. Psiko-Motor Gelişim. Ankara

National Autism Center (2009). National standarts report In S.M. Wilczynski (Eds.).

Parsons, S., \& Mitchell, P. (2002). The potential of virtual reality in social skills training for people with autistic spectrum disorders. Journal of Intellectual Disability Research, 46(5), 430-443.

Piek, J.P., \& Dyck, M.J. (2004). Sensory motor deficits in children with developmental coordination disorder, attention defisit hyperactivity disorder and autistic disorder. Human Mov Sci. 23:475-488.

Rice, L. M., Wall, C. A., Fogel, A., \& Shic, F. (2015). Computer-assisted face processing Instruction Improves emotion recognition, mentalizing, and social skills in students with ASD. Journal of autism and developmental disorders, 1-11. 
Simpson, A., Langone, J., \& Ayres, K. M. (2004). Embedded video and computer based Instruction to Improve social skills for students with autism. Education and Training in Developmental Disabilities, 240-252.

Sucuoğlu, B., Diken, İ.H., Demir, Ş., Ünlü, E. ve Şen, A. (2010). Özel eğitim terimler sözlüğü. Ankara: Maya Akademi

Tanaka, J. W., Wolf, J. M., Klaiman, C., Koenig, K., Cockburn, J., Herlihy, L., Brown, C., Stahl, S., Kaiser, M.D., \& Schultz, R. T. (2010). Using computerized games to teach face recognition skills to children with Autism Spectrum Disorder: The Let's Face It! program. Journal of Child Psychology and Psychiatry, 51(8), 944-952.

Tekin-Ersan, D. (2015). Problem çözme eğitiminin otizm spektrum bozukluğu olan çocuk annelerinin problem çözme becerileri ve bazı psikolojik değişkenler üzerindeki etkisi. Anadolu Üniversitesi Eğitim Bilimleri Enstitüsü. Yayımlanmamış Doktora Tezi.

Thomeer, M. L., Smith, R. A., Lopata, C., Volker, M. A., Lipinski, A. M., Rodgers, J. D., McDonald, C.A., \& Lee, G. K. (2015). Randomized controlled trial of Mind Reading and in vivo rehearsal for high-functioning children with ASD. Journal of autism and developmental disorders, 1-13.

Toper-Korkmaz, Ö. (2012). Basmakalıp (stereotipik) davranışların azaltılmasında yeni bir strateji: tepkiyi yarıda kesme ve yönlendirme. Özel Eğitim Dergisi, 13(1).

Vuran, S. ve Sönmez, M. (2008). Sosyal geçerlik kavramı ve Türkiye'de özel eğitim alanında yürütülen lisansüstü tezlerde sosyal geçerliğin değerlendirilmesi. Ankara Üniversitesi Eğitim Bilimleri Fakültesi, 9(1), 55-65.

Yıldırım, A. ve Şimşek, H. (2008). Sosyal bilimlerde nitel araştırma yöntemleri. (6. Baskı). Ankara: Seçkin Yayıncılık 
Otizm Spektrum Bozukluğu Olan Bireylere Sosyal Beceri Öğretiminde Bilgisayar Destekli Öğretim Uygulamalarının Gözden Geçirilmesi

Mine KiziR - Ahmet YIKMIŞ

\section{SUMMARY}

Autism Spectrum Disorder (ASD) is defined as a neurodevelopmental disorder that emerges in social settings and manifests itself with disabilities in communication and interaction and limited, repetitive behaviors, interests or activities. There are several interventions that facilitate the participation of individuals with ASD within the social life and aim to endorse their acquisition of social skills. In accordance with the NAC report, it is observed that 27 of the applied interventions meet the scientifically based criteria. Hence, social stories, differential reinforcement, being a model, natural approaches, basic response training, peer teaching, positive behavior support, discrete trials and visual support are particularly scientifically based practices. One of the mentioned scientifically based practices is technology based teaching and intervention method. The method comprises various practices in the context of technology. Speech generating devices, smart phones, tablets, virtual networks and Computer-Based Instruction / CBI are within this context.

There is certain need to develop an array of software in order to conduct educational activities in CBI. The software developed with such purpose could be used in almost all areas of education. The use of $\mathrm{CBI}$ in education is highly beneficial. These benefits could be listed as motivating the students, being attractive, providing permanent experiences, developing skills and behaviors as well as the knowledge, delaying oblivion in teaching, rendering teaching enjoyable, attractive and entertaining, having richness in application, performing the appropriate training needs. Besides, students and teachers have more time due to the effect that speeds up the learning process. Given the possibility of computer generated simulations and models, students could easily perceive and keep things in mind, with the chance of repetition. In addition, it allows students to actively participate the learning process and to learn subjects at their own pace. Aforementioned benefits of $C B I$ could be affirmed valid for individuals with ASD, and in addition it could be stated that using $\mathrm{CBI}$ in their education would reduce the negative emotions they feel in social settings due to software such as virtual reality.

The main purpose of this research is to provide the necessary information, which practitioners and researchers working on social skill education of individuals with ASD might sought, through a systematic review. Document review, which is a method of qualitative research, was used as the methodology of this study in order to conduct the analysis of the acquired research within the scope of this study. Certain criteria were established in order to determine the research to be included in this study. The primary criterion is that the research should be conducted experimentally between 2005 and 2015, and be published in a peer-reviewed journal. The second criterion is that the participants should be diagnosed with ASD. Another criterion is the research are experimental and targets the use of $\mathrm{CBI}$ in teaching one or more social skills. It was possible to access 13 research that fulfill the above-mentioned criteria. In skimming the articles, EBSCO-Host, ERIC, PsycINFO, Academic Search Complete and Google electronic databases were used on the database system of Muğla Sıtkı Koçman University. Keywords such as Autism Spectrum Disorder, Asperger Syndrome, Pervasive Developmental Disorders, social skill, social skill training/teaching, Computer Based Intervention/ Computer Assisted Instruction/ Technology/Training were used in the process of skimming the articles to be included within this study. All research accessed were reviewed focusing on their titles and abstracts, and those which did not fulfill the criteria were not included in this research. The accessed research papers were assigned numbers with respect to their year of employment, from the oldest to the most recent. Latter, the categories were identified by the researchers. The categories related to the reviewed research in the scope of this study are: (a) age, gender, diagnosis and participant characteristics including the number of participants, (b) targeted social skills, research design, method features including social validity and reliability data, (c) application properties comprising software, hardware, environment, duration and application and (d) concluding findings comprised of information on effectiveness, monitoring and generalization.

The 13 research papers that were reviewed present a total of 401 participants. According to gender characteristics 338 of the participants are male and 63 are female. The age range of participants demonstrate variations. It is possible to assert that the research papers mainly cluster around 5-12, 1217, and 17 and older age ranges. None of the reviewed research focused on individuals in early childhood. "Mind Reading", "Collaborative Virtual Learning Environment (CVLE) - 3D Empathy System", "FaceSay" ${ }^{\mathrm{TM}}$ ", "Junior Detective Training Program", "MS PowerPoint and Adobe Photoshop 5.0", "Let's 
Face It", "The Educational Software" and "Virtual Reality Social Cognition Training" software were used in the reviewed research. Findings related to the method characteristics were examined under the topics of targeted social skills, research design, social validity and reliability and findings related to the application; data on the use of software and hardware, environment in which the application takes place, the duration, execution of the application, generalization studies and effectiveness were presented in a systematic way.

In conclusion, it was determined that all reviewed research were effective in teaching the targeted social skills. Besides, in studies that conduct a generalization study, it was stated that acquired skills could be generalized despite limitations. In order to utilize CBI, a scientifically based method, in Turkey it is necessary to develop software that are appropriate to Turkish culture, modes of communication education system, etc. In addition, the software that were developed up till now should be studied on to reach a wider audience. 